\title{
Anti-cancer property of Lenzites betulina (L) Fr. on cervical cancer cell lines and its anti-tumor effect on HeLa-implanted mice
}

\author{
Tapojyoti Sanyal ${ }^{1} *$ Swapan Kumar Ghosh ${ }^{1}$ \\ ${ }^{1}$ Molecular Mycopathology Lab, Cancer Research Unit, PG Dept. of Botany, \\ Ramakrishna Mission Vivekananda Centenary College (Autonomous), Rahara, Kolkata 700118, India. \\ *Corresponding author: gswapan582@gmail.com
}

\begin{abstract}
In global scenario cervical cancer is increasing. New drugs from natural compounds are in search. Mushrooms are now recognized as miniature pharmaceutical factories producing hundreds of novel constituents. We have taken ethanolic extract Lenzities betulina (LBE) wild mushroom for evaluation of its as anti-cancer property against cervical cancer cell lines e.g. HeLa, CaSki and SiHa and anti tumor activity against HeLa implanted tumor on mice. The extraction was done by dip and stirring method in $90 \%$ ethanol for $72 \mathrm{~h}$. For evaluation of anti-cervical cancer, several assays were performed such as MTT assay, cell morphology by phase contrast microscope and F-action polymerization by Laser scanning confocal microscope and nuclear morphology DAPI staining under inverted fluorescence microscope, MMP, ROS, cell cycle, autophagy and stem cell population by flow cytometry and DNA laddering were done. Western blotting was done for protein expression. To evaluate anti- metastatic activity, anti- cologenic assay and wound healing assay were adopted. For chemo- analysis of the LBE, GC-MS was done. The results from Cytotoxicity assay showed that at highest dose of LBE $(1000 \mu \mathrm{g} / \mathrm{ml})$ after $24 \mathrm{~h}$, percentage of cell inhibitions were $85.13 \%, 77.13 \%$ and $47.70 \%$ against HeLa , CaSki and SiHa respectively and the calculated $\mathrm{IC}_{50}$ values were $492.52 \pm 2.6$ $\mu \mathrm{g} / \mathrm{ml}, 612.22 \pm 4.2 \mu \mathrm{g} / \mathrm{ml}$, and $1210.30 \pm 6.4 \mu \mathrm{g} / \mathrm{ml}$ respectively . Depending upon the cytotoxicity screening, HeLa cell line was considered for the further studies. Cell morphology study exhibited that LBE treated HeLa cells became round from normal spindle shape. DAPI staining showed that LBE treated nucleus became condensed and fragmented. DNA fragmentation at 230 and 300 base pair zone from agarose gel assay was observed. LBE induced ROS generation and reduced MMP. It up regulated the expression of apoptotic genes and p53 while down regulated Bcl2, pro- caspase 3 and pro caspase-9 gene. Cell cycle was arrested at G2/M checkpoint. Autophagic induction was exhibited by vacuole formation in treated cells. CSC population of treated cells was reduced and F- actin polymerization was observed in treated cells. In addition, LBE suppressed metastatic nature by inhibition of cell migration and colonization. The inhibition of growth of the tumors in HeLa cell-implanted mice showed that treatment with $50 \mathrm{mg} \mathrm{LBE} / \mathrm{kg}$ of body weight of mice led to a marked reduction in the volume $(93.22 \pm$ $9.2 \%)$ and weight $(90.42 \pm 9.55 \%)$ of the tumors. The GC-MS profile of LBE shows that out of 69 compounds, 9, 12-Octadecadienoic acid (Z, Z) and Ergosta-5, 8, 22-trien-3-ol, (3.beta22E) are in a significantly higher proportion with the percentage peak area 22.13 and 19.72 respectively. Library search for bioactivity showed that these compounds are anti-cancerous and interestingly 4'-Hydroxy-6methoxyaurone binding with P-glycoprotein inhibits the cancer cells to become drug resistant. In conclusion, LBE is very prominent anti-cervical cancer having a lot of anti-cancerous compounds which are probably acting synergistically. This report of anti- cervical cancer property of L. betulina is probably first time in oncology. Its therapeutic use in human model is urgent for new drug development.
\end{abstract}


Keywords: Lenzites betulina, ethanolic extract, HeLa, SiHa , CaSki cell, cervical cancer, tumor, cytotoxicity, apoptosis, migration, colonization, autophagy, metastasis, tumor, mice

\section{INTRODUCTION}

Mushrooms or macrofungi offer high sources of new isolable bioactive compounds with diversified chemical structures, which are considered potent sources for drug discovery. In the stone era, human went for hunting and the same time collect food including mushrooms for organoleptic properties such as flavor and texture ${ }^{1-3}$ and then realized that some of mushrooms have properties for curing certain ailments. Local consumption of wild mushrooms are also increasing because of their medicinal properties ${ }^{4,5}$ due to the presence of secondary metabolites having pharmaceutical importance..$^{3,4}$ There are more than 14,000 mushrooms out of 5.1 million estimated fungi, among which near about 700 exhibit medicinal properties ${ }^{6}$. Lenzitis betulina (L) Fr. belongs to the family Polyporaceae, order Polyporales and phylum to Basidiomycota, and grows on logs and fallen woods. Various species of Lenzites are well distributed around the world. Lenzitis spp have no value as food since it has an extremely tough exterior ${ }^{7}$. There have been different studies on the various medicinal uses of Lenzites spp. antimicrobials ${ }^{8,}{ }^{9}$, anti-viral ${ }^{10}$, and immunosuppresser ${ }^{11}$. Phytochemical analysis of compounds presents in Lenzites spp. using three different solvents (ethanol, water and petroleum ether) showed that phenolic and steroids were present in the ethanol extract; flavonoids, tannins and steroids were present in the petroleum ether and only saponins were present in the aqueous extract ${ }^{9}$. Since many of the compounds have been shown to act synergistically, it is worth testing the anti-proliferative effects of the whole mushroom extract rather than its individual components. This principle (synergy) is compatible with similar natural biological products like the essential oils, which are more effective when used as whole products, while quenching or nullifying potential unwanted side-effects by the presence of individual components ${ }^{12}$. Among mushroom extracts, an ethanol extract probably finds the most extensive application ${ }^{13}$. Cancer is a major public health problem and one of the leading causes of death in the world today ${ }^{14}$. Cervical cancer is the second most common cancer among women worldwide ${ }^{15,16}$. One third of newly diagnosed cancers among women in the India are cervical cancers and that is for the infection with some types of HPV (Human Papilloma Virus). Every year in India, 122,844 women are diagnosed with cervical cancer and 67,477 die from the disease ${ }^{17} 18$. The current anti-cancer drugs i.e. chemo- drugs available in market are not target specific and pose several sideeffects and complications in clinical management of various forms of cancer ${ }^{19}$, which highlights the urgent need for novel effective and nontoxic natural compounds ${ }^{20,21}$. Epidemiological studies showed that among the Chinese women who regularly intake powder of Agaricus bisporus with tea have less breast and gastrointestinal (GI) cancers ${ }^{22}$. Consumption of mushroom has inverse effect in breast cancers occurrence among premenopausal women ${ }^{23}$. Lucas et al. ${ }^{24}$ got the first credit to show that mushroom extract has antitumor properties using extracts of Boletus edulis and other basidiomycetes against Sarcoma-180 and also on HeLa cell lines presenting significant growth inhibition on those types of cancer. Ikekawa et $a l^{25}$ published one of the first scientific reports on antitumor activity of extracts of mushrooms against implanted Sarcoma 180 in animals. Soon after, three major anticancer drugs, Krestin from cultured mycelium of Trametes (Coriolus versicolor), Lentinan from fruiting bodies of Lentinus edodus and Schizophyllan from Schizophyllum commune, were developed ${ }^{26-28}$. We came to know from the review work of Dai Yu-C et al ${ }^{29}$, that 200 to 331 of mushroom species have anticancer activity. Near about 650 species of higher basidiomycota have been found anti-cancer activity $^{26}$. Although Lenzites betulina is worldwide distributed, there has been minimal or no extensive research work on it for cancer remedy. Therefore, the main objectives of this work are to screen 
cytotoxicity effect of ethanolic extract of Lenzites betulina ( LBE ) aganist HeLa ,CaSki and SiHa cell lines of cervical cancer, to evaluate anti proliferative, apoptotic, autophagic activity, effect on cancer stem cell and anti-metastatic ( anti migration /anti-invasion and anti-colonization) activity of LBE on HeLa cell line, to evaluate antitumor effects of LBE in HeLa-implanted mice and to find out chemo profile by Gas chromatography and mass spectrometry (GC-MS).

\section{MATERIALS AND METHODS}

\section{Materials}

The fruit bodies of Lenzites betulina (L) Fr were collected from dead logs from Baruipure, South 24 Parganas, West Bengal of India and carried to laboratory by biodegradable carry bag and identification was done by morphological and anatomical analysis consulting with mushrooms keys, manuals and books ${ }^{30-32}$.One voucher specimen was kept in Fungal Herbarium of Department of Botany, Ramakrishna Mission VC College, and Rahara. Remaining were washed by running tap water, blotted by blotting papers and kept at $50^{\circ} \mathrm{C}$ in oven for $48 \mathrm{~h}$ for drying.

\section{Preparation of ethanol extract (LBE)}

The collected and identified fruit bodies of L. betulina (LB) after oven dried at $50^{\circ} \mathrm{C}$ temperature for 48 $\mathrm{h}$ were ground by mixture grinder (Beckman food mixer, India). This smashed biomass (100 g) was suspended in $500 \mathrm{ml}$ of $90 \%$ ethanol and incubated for $72 \mathrm{~h}$ at $200 \mathrm{rpm}$ and $37^{\circ} \mathrm{C}$. The suspension was filtered on what man No. 4 paper to remove the biomass. This procedure was repeated thrice. The supernatant was concentrated and ethanol was subsequently removed from the extract using a rotary vacuum evaporator at $40^{\circ} \mathrm{C}$, and the remaining solvent was removed with a freeze-drier. The resulting dried powder stored at $4^{\circ} \mathrm{C}$. The stock solution of $\mathrm{LBE}(\mathrm{LBE})$ was prepared by dissolving in dimethylsulphoxide (0.2\% DMSO) at a concentration $10 \mathrm{mg} / \mathrm{ml}$ and stored at $4{ }^{\circ} \mathrm{C}$.

\section{Cell culture}

HeLa, CaSki and SiHa human cell line obtained from NCCS Pune were maintained in Dulbecco's modified Eagle's medium (DMEM) containing penicillin $(50 \mathrm{U} / \mathrm{ml})$, streptomycin $(50 \mathrm{U} / \mathrm{ml})$ and $10 \%$ fetal bovine serum (FBS). The cultures were maintained at $37^{\circ} \mathrm{C}$ in $5 \% \mathrm{CO}_{2}$ and $95 \%$ humidity in $\mathrm{CO}_{2}$ incubator (Thermo scientific, USA). 


\section{Chemicals}

3-(4,5- dimethyl thiazol-2-yl)-5-diphenyltetrazolium bromide (MTT), Fetal Bovine Serum(FBS), Phosphate Buffered Saline (PBS), Dulbecco's Modified Eagle's Medium (DMEM), and Trypsin were obtained from Himedia Laboratory. EDTA, glucose, and antibiotics from Himedia Laboratories, Dimethyl Sulfoxide(DMSO) from Cell Clone and Propanol from Thermo Fisher Scientific. JC1 (Thermo Fisher Scientific), RIPA (Radioimmunoprecipitation assay buffer), $\mathrm{H}_{2}$ DCFDA (Thermo Fisher Scientific) L-ascorbic acid (SRL), DPPH (SRL) $\mathrm{H}_{2} \mathrm{O}_{2}$ (Merck). Annexin-V kit from Santacruze Biotechnology,USA. Anti-mouse antibodies against p53, Beta actin, Bcl-2, pro-caspase-3, pro-caspase9, PARP, were procured from Santa Cruz USA Nitrocellulose membrane and filter papers were obtained from Bio-Rad. Dapi(Thermo Fisher Scientific ) Ethanol were HPLC grade and were purchased from Merck. Alexa Fluor 488 Phalloidin and Hoechst 33342 (Thermo Fisher Scientific). The others chemicals and materials were purchased from local firms (India).

\section{Cell lines, culture medium and subculture of cell line}

Human Cervical Cell lines (HeLa, CaSki and SiHa) were grown and maintained in DMEM (Dulbecco's Modified Eagle's) Medium supplemented with L Glutamine, 10\% FBS, sodium bicarbonate in T25 cell culture flasks to the $80-90 \%$ confluence. The media also supplemented with $1000 \mu \mathrm{g} / \mathrm{ml}$ streptomycin (Himedia) and $1000 \mathrm{IU} / \mathrm{ml}$ penicillin (Himedia) at $37^{\circ} \mathrm{C}$ in a humidified atmosphere of $5 \% \mathrm{CO}_{2}$. Maintenance cultures were passaged weekly, and the culture medium was changed twice a week ${ }^{33}$.

\section{Cytotoxicity / cell proliferation assay}

MTT colorimetric assay method was employed to evaluate cell viability in this cytotoxic assay. Cells of HeLa, SiHa and CaSki were seeded in a 96 well plate $\left(1 \times 10^{4}\right.$ cells/well in $100 \mu \mathrm{l}$ of medium) separately and treated for 24, 48 and $72 \mathrm{~h}$ with 100, 250, 500, 750 and $1000 \mu \mathrm{g} / \mathrm{ml} \mathrm{LBE}$. After incubation the media was discarded and $100 \mu \mathrm{l} /$ well MTT (Himedia Laboratory) reagents were added into each well and the cells incubated for another 2-4 $\mathrm{h}$ until purple precipitates were clearly visible under a microscope. Flowingly, the medium together with MTT (100 $\mu 1)$ were aspirated off the wells, DMSO $(100 \mu \mathrm{L})$ was added and the plates shaken for $5 \mathrm{~min}$. The absorbance for each well was measured at $540 \mathrm{~nm}$ in a micro-titre plate reader (Bio-Rad i-mark). The $\mathrm{IC}_{50}$ values of LBE were calculated

The concentration which led to a $50 \%$ killing $\left(\mathrm{IC}_{50}\right)$ was calculated by plotting a dose response graph of the cytotoxicity values obtained using the formula given below:

$\% \mathrm{X}=100-\left\{\left(\frac{y-z}{y}\right) \times 100\right\}$, Where $\mathrm{x}=\%$ of cell Cytotoxicity, $\mathrm{y}=$ Control, $\mathrm{Z}=$ test. Data points represent the mean $\pm \mathrm{SD}$ in one experiment repeated at least thrice. 


\section{Morphological examination of HeLa cancer cells}

HeLa cancer cells were grown in 6 well -culture plate and treated with LBE $(0,500 \mu \mathrm{g} / \mathrm{ml}$ and $1000 \mu \mathrm{g}$ $/ \mathrm{ml}$ ). Cells were examined under phase contrast inverted microscope (Olympus,Japan) and photographs were taken using a digital camera (Q Imaging) for analysis.

\section{4, 6-Diamidino-2-phenylindole (DAPI) nuclear staining}

HeLa cells were cultured in cover slip in 6 well plates and treated with 500 and $1000 \mu \mathrm{g} / \mathrm{ml}$ of LBE and incubated at $37^{\circ} \mathrm{C}$ for $24 \mathrm{~h}$. After incubation cells were washed with PBS in three times and the cells were fixed in $3.7 \%$ formaldehyde for $10 \mathrm{~min}$ then the cells were rinsed into PBS + for three times, $0.2 \%$ Triton X-100 was added and incubated for $5 \mathrm{~min}$. After incubation the cells were washed with PBS and DAPI was added, and incubated for $5 \mathrm{~min}$, the solution was discarded and again the cells were washed with PBS in three times. After washing cells were observed under the fluorescence microscope (Olympus inverted fluorescence microscope CKX 53)

\section{Effect of LBE on the mitochondrial membrane potential (MMP) of HeLa cells}

Mitochondrial outer membrane permeability was measured by flow cytometry using the MitoProbe ${ }^{\mathrm{TM}}$ JC-1 Assay Kit, Thermo Fisher Scientific. HeLa cells were cultured in 6 well plates and treated with 250 and $500 \mu \mathrm{g} / \mathrm{ml}$ of LBE and incubated at $37^{\circ} \mathrm{C}$ for $6 \mathrm{~h}$ and $12 \mathrm{~h}$. After incubation cells were washed twice with PBS and incubated with $10 \mu \mathrm{l}$ of $200 \mu \mathrm{M} \mathrm{JC1}$ at $37^{\circ} \mathrm{C}, 5 \% \mathrm{CO}_{2}$ for 30 min, cells were washed once by adding $2 \mathrm{ml}$ of warmed phosphate-buffered saline (PBS) to each tube of cells. The cells were pelleted by centrifugation and re-suspended by gently flicking the tubes. $500 \mu \mathrm{l}$ PBS was added to each tube and analyzed on a flow cytometer with $488 \mathrm{~nm}$ excitation using emission filters appropriate for Alexa Fluor 488 dye and R-phycoerythrin. A gate on the cells, excluding debris. Using the CCCP-treated sample, standard compensation intensity was determined by flow cytometry. Cells with reduced fluorescence were counted as having lost some of their mitochondrial membrane potentials.

\section{Detection of Intracellular ROS(Reactive oxygen species) by $\mathrm{H}_{2} \mathrm{DCFDA}$}

ROS were detected by the modified method of Deem TL, Cook-Mills JM. ${ }^{6} 1 \times 10^{5}$ cells were cultured in $35 \mathrm{~mm}$ plates and treated with $500,750 \mu \mathrm{g} / \mathrm{ml}$ of LBE and incubated at $37^{\circ} \mathrm{C}$ at $2 \mathrm{~h}$. After incubation cells were trypsinized and suspended in 500 $\mu$ l PBS (1x), $5 \mu 1 \mathrm{H}_{2}$ DCFDA (Thermo Fisher Scientific) was added and incubated for $30 \mathrm{~min}$ at $37^{\circ} \mathrm{C}$.then analyze the sample in Flow Cytometer (FACS Calibur, BD Bioscience). Where Ascorbic acid acts as a positive control and $\mathrm{H}_{2} \mathrm{O}_{2}$ acts as a negative control. Also we observed ROS by inverted fluorescence microscopy. 


\section{Cell cycle analysis}

For the determination of cell cycle phase distribution of nuclear DNA. Cells were treated with 100, 250, $500 \mu \mathrm{g} / \mathrm{ml} \mathrm{LBE}$ and incubate for 6 and $12 \mathrm{~h}$. After incubation cells were fixed with 3\% pformaldehyde, permeabilized with $0.5 \%$ Triton X-100, and nuclear DNA was labeled with propidium iodide (PI, $125 \mathrm{mg} / \mathrm{ml}$, Santacruze Biotechnology, USA) after RNase treatment. Cell cycle phase distribution of nuclear DNA was determined on FACS Calibur using Cell Quest software (Becton Dickinson). Histogram of DNA content (x-axis, PI fluorescence) versus counts (y-axis) has been displayed. Cell Quest statistics was employed to quantities the data at different phases of the cell cycle.

\section{Annexin V-FITC apoptosis assay}

In general phosphatidyl-serine (PS) exists in internal face of plasma membrane but in early apoptosis it comes to external face of the plasma membrane, the high affinity PS binding protein Annexin V (conjugated to fluoresce in isothiocyanate FITC) which has high affinity to PS binding is used to identify the early event of HeLa cell killing caused by the LBE. On the other hand, simultaneously counterstaining propidium iodide (PI) is applied which allowed the differentiation of necrotic and apoptotic cells. An Annexin v-fluoresce in isothiocyanate (FITC)/ propidium iodide apoptosis detection kit (Santa cruze Biotechnology, USA), according to the manufacturer's protocol, was applied to calculate cell apoptosis. In this study, percent of apoptotic and necrotic cells were determined after treatment with the LBE $(250,500,750$ and $1000 \mu \mathrm{g} / \mathrm{ml})$ by flow cytometry using the AnnexinV-FITC apoptosis detection kit (Santacruze Biotechnology). Briefly, PI and Annexin-V were added to the cell line .The mixture was incubated for $15 \mathrm{~min}$ at $37^{\circ} \mathrm{C}$, and then analyzed on FACS Verse. Electronic compensation of the instrument was done to exclude overlapping of the emission spectra. Total 10,000 events were acquired, the cells were properly gated and dual parameter dot plot of FL1-H (x-axis; FLUOS-fluorescence) versus FL2-H (y-axis; PI-fluorescence) was performed and shown in logarithmic fluorescence intensity.

\section{DNA fragmentation assay/ DNA Laddering assay}

The DNA ladder assay was sensitive, cost-effective and most useful method for estimating apoptosis. $2 \times 10^{5}$ cells were cultured into 6 well plates and treated with 500,750 and $1000 \mu \mathrm{g} / \mathrm{ml} \mathrm{of}$ LBE and incubate at $37^{\circ} \mathrm{C}$ for $48 \mathrm{~h}$. After treatment, DNA was isolated from HeLa cell line and visualized after the separation by gel electrophoresis $(1.8 \%$ agarose gel containing Etbr in $40 \mathrm{Mm}$ Trisacetate with electrophoresis at $75 \mathrm{~V}$ at $4 \mathrm{~h}$.)

\section{Autophagy assay by acridine orange}

$2 \times 10^{5}$ cells were cultured in 6 well plates and treated with 250 and $500 \mu \mathrm{g} / \mathrm{ml}$ of LBE and incubated at $37^{\circ} \mathrm{C}$ at $24 \mathrm{~h}$. After incubation cells were trypsinized and suspended in $500 \mu \mathrm{PBS}(1 \mathrm{x})$, add $1 \mu \mathrm{g} / \mathrm{ml}$ acridine orange and incubate for $30 \mathrm{~min}$ at $37^{\circ} \mathrm{C}$. The sample was then detected using Flow cytometry (FACS Calibur, BD Bioscience) and data were analyzed 


\section{F-actin staining}

$2 \times 10^{5}$ cells $(\mathrm{HeLa})$ were cultured in 6 well plates and incubated at $37^{\circ} \mathrm{C}$ at $24 \mathrm{~h}$. After incubation cells were treated with LBE $(750 \mu \mathrm{g} / \mathrm{ml})$ and incubate at $37^{\circ} \mathrm{C}$ at $24 \mathrm{~h}$. After incubation cells were washed with 1x PBS and fixed with 3.7\% formaldehyde. After fixation $0.2 \%$ Triton $X$ was added and incubated for $2 \mathrm{~min}$ and then Alexa flour 488 Phalloidin (1:500) was added for $1 \mathrm{~h}$ in room temperature. Finally cells were stained by DAPI and the sample was then detected using confocal microscopy (Olympus, Japan) and data were analyzed.

\section{Hoechst efflux assay for cancer stem cell population study}

$2 \times 10^{5}$ cells $(\mathrm{HeLa})$ were cultured in 6 well plates and treated with 250 and $500 \mu \mathrm{g} / \mathrm{ml}$ of LBE and incubated at $37^{\circ} \mathrm{C}$ at $24 \mathrm{~h}$. After incubation cells were trypsinized and suspended in $500 \mu 1 \mathrm{PBS}(1 \mathrm{x})$, verapamil $50 \mu \mathrm{g} / \mathrm{ml}$ was added and incubated for $30 \mathrm{~min}$ at $37^{\circ} \mathrm{C}$. After verapamil treatment, cells were washed with PBS (1x) for 3 times, Hoechst $(1 \mu \mathrm{g} / \mathrm{ml})$ was added and incubated for 30 min in $37^{\circ} \mathrm{C}$. The sample was then detected using Flow cytometry (FACS Calibur, BD Bioscience) and data were analyzed.

\section{Western blot analysis}

HeLa $\left(2 \times 10^{5}\right)$ cells were treated with $100,200,500$ and $750 \mu \mathrm{g} / \mathrm{ml}$ of LBE for $24 \mathrm{~h}$. After treatment, cells were lysed with RIPA buffer (Abcam). The effect of treatment on the expression of certain cell cycle proteins such as p53, and on apoptotic proteins such as Bcl-2, pro-caspase-3, pro-caspase-9, and PRAP (Santacruze Biotechnology, USA) was determined. Proteins were detected by incubation with the corresponding primary antibodies, and antibodies followed by blotting with the HRP-conjugated secondary antibody. The blots were then detected using Luminol (Bio-Rad).

\section{Wound healing/ scratch assay}

HeLa $\left(50 \times 10^{3}\right)$ cells were seed in a 24 well plate and incubate at $37^{\circ} \mathrm{C}$ for $24 \mathrm{~h}$. After $80-90 \%$ confluences, $200 \mu \mathrm{l}$ micro tips used to press firmly against the top of the cell culture plate and a vertical wound down through the cell monolayer was swiftly made and then discarded the media carefully and each wall was washed with 1x PBS and finally treated with 500,1000 $\mu \mathrm{g} / \mathrm{ml}$ of LBE and a snap (zero h) through inverted fluorescence microscope (Olympus inverted fluorescence microscope, Japan) were taken and the culture plate was placed into $\mathrm{CO}_{2}$ incubator $\left(37^{\circ} \mathrm{C}, 5 \% \mathrm{CO}_{2}\right)$. After $24 \mathrm{~h}$ incubation plates were removed and placed it in an inverted fluorescence microscope to take a snap (Olympus inverted fluorescence microscope, Japan) and sample was analyzed by Q Capture pro-7.

\section{Cologenic assay}

HeLa (500) cells per well were seeded in a 6 well cell culture plate and incubated at $37{ }^{\circ} \mathrm{C}$. Immediately after attachment the cells were treated with $(250,500,750,1000$ and $1250 \mu \mathrm{g} / \mathrm{ml}) \mathrm{LBE}$ for 4 days of interval. Cells were treated with same concentration of extract then colonies were fixed with $3.7 \%$ formaldehyde and stained with $(0.5 \% \mathrm{w} / \mathrm{v})$ crystal violet. Viable colonies were counted using Olympus inverted fluorescence microscope (CKX 53).Colonies consisting of more than 50 cells 
were counted by using a colony counter and the results were reported as a percentage of colonies formed using the following equation: \% Colonies formed $=$ Colonies formed in treated sample /Colonies formed in untreated sample X100.

\section{Antitumor effects of $\mathrm{LBE}$ in HeLa cell-implanted mice}

Male Swiss Albino mice (20-30 g) were used for the present investigation. The animals were kept in well ventilated cages (one group per cage) and provided with standard laboratory rodent diet ad libitum along with free access of water .Prior to commencement of experiments, all the animals were kept for four weeks under controlled temperature $\left(25 \pm 2{ }^{0} \mathrm{C}\right)$ and humidity $(50-70 \%)$ with $12 \mathrm{~h}$ day/night cycle for acclimatization. All mice were housed under hygienic /pathogen-free air conditions in a room maintained at $24^{\circ} \mathrm{C}$ with $50 \%$ relative humidity and a $12 \mathrm{~h} / 12 \mathrm{~h}$ light-dark cycle. All animal experiments were approved and performed according to the regulations of the Institutional Animal Ethics Committee, Government of India (approval no: 12/P/S/ IAEC/2018). The mice were divided into 6 groups:) control mice supplemented with pellet (control + vehicle; $n=6$ );ii) controls supplemented with LBE (500 mg/kg of body weight) (control + LBE; $n=6)$; iii) HeLa cell-implanted mice supplemented with pellet (HeLa + vehicle; $n=6)$; iv) HeLa cell-implanted mice supplemented with LBE $(10 \mathrm{mg} / \mathrm{kg}$ of body weight) (HeLa + LBE 10;n=6);v) HeLa cell-implanted mice supplemented with LBE (25 mg/kg of body weight) (HeLa + LBE 25, $n=6)$; and vi) HeLa cellimplanted mice supplemented with LBE $(50 \mathrm{mg} / \mathrm{kg}$ of body weight $)(\mathrm{HeLa}+\mathrm{LBE} 50, n=6)$.

For tumor generation, a suspension of $2 \times 10^{6} \mathrm{HeLa}$ cells in $0.2 \mathrm{ml}$ DMEM was subcutaneously injected on the dorsal surface of the right hind legs of the Swiss albino mice, where as the control groups were injected with DMEM. The tumors were measured with Vernier calipers every 3-4 days by using the formula $a^{2} \times b \times 0.52$ (where $a$ is the shortest diameter and $b$ is the longest diameter). When the tumor volume was measured to be $0.50-0.90 \mathrm{~cm}^{3}$, the mice were randomized. Subsequently, the mice were supplemented daily with vehicle or LBE at the doses of 10,25 , and $50 \mathrm{mg} / \mathrm{kg}$ of body weight for 28 days. After 28 days, all the mice in groups 3-6 were sacrificed, and the tumors were excised from their legs and then weighed. Visceral organs (i.e., the kidney, liver, spleen and lungs) were morphologically observed for possible side effects of LBE in the mice.

\section{Statistical analysis}

All data were analyzed using Graph Pad Prism 5 software (Graph Pad Software, Inc., La Jolla, CA, USA), and one-way analysis of variance was performed to compare differences between the groups. All results are presented as the mean \pm standard error of mean from three independent experiments performed in a parallel manner, unless otherwise indicated. All figures shown in the present study were obtained from at least three independent experiments. $\mathrm{P}<0.05$ was considered to indicate a statistically significant. 


\section{Gas chromatography-mass spectrometry (GC/MS) analysis}

GC/MS analysis was done by Agilent Technologies, GC-6860N Network System with inert Mass Selective Detector and the search library used by C: $\backslash$ Database $\backslash$ NBS75K.L. Applying HP-5MS (19091S-602) Column the length and thickness of column was respectively $30 \mathrm{~m}$ and $0.25 \mathrm{~mm}$. The carrier gas was Helium gas $(99.99 \%)$ used at a flow rate of $1 \mathrm{ml} / \mathrm{min}$ and an injection volume of $2 \mu 1$. Injector temperature was $280^{\circ} \mathrm{C}, 70 \mathrm{ev}$ ion source temperature $280^{\circ} \mathrm{C}$. The oven temperature was $50^{\circ} \mathrm{C}$ isothermal for $2.0 \mathrm{~min}$, with an increase of $10^{\circ} \mathrm{C} / \mathrm{min}$ to $280^{\circ} \mathrm{C}$, then $10^{\circ} \mathrm{C} / \mathrm{min}$ to $300^{\circ} \mathrm{C}$, and ending with $10 \mathrm{~min}$ isothermal at $280^{\circ} \mathrm{C}$.

\section{RESULTS}

\section{Cytotoxicity / anti proliferative of LBE against HeLa cell line by MTT assay}

It was investigated that whether LBE affected HeLa, CaSki and SiHa cell proliferation or not. The cell proliferation graph of the HeLa cell line (Fig1 A, B, C) exhibited that untreated (negative control) cells proliferated at the expose time periods $(24,48$ and $72 \mathrm{~h}$ ). In contrast, cells were treated with LBE at all tested concentrations, showed reduced proliferation in concentration and time dependent manners in all cell lines (HeLa, CaSki and SiHa). Cells were treated with higher concentration $(1000 \mu \mathrm{g} / \mathrm{ml})$ of LBE proliferated least $(14.87 \%, 22.87 \%, 52.30 \%)$ respectively. It indicated the percentage of cell inhibition were $85.13 \%, 77.13 \%$ and $47.70 \%$ against HeLa , CaSki and SiHa (Fig 2A, B) at $24 \mathrm{~h}$ and 1000 $\mu \mathrm{g} / \mathrm{ml}$ of LBE .In case of HeLa percentage of cell inhibition was increase as dose and time dependent manner. After calculating the data presented in graph 1, the $\mathrm{IC}_{50}$ value i.e. the concentration of $\mathrm{LBE}$ that resulted in a 50\% reduction in absorbance compared with the control (negative) after $24 \mathrm{~h}$ of treatment, were $492.52 \pm 2.6 \mu \mathrm{g} / \mathrm{ml}, 612.22 \pm 4.2 \mu \mathrm{g} / \mathrm{ml}$, and $1210.30 \pm 6.4 \mu \mathrm{g} / \mathrm{ml}(\mathrm{HeLa}, \mathrm{CaSki}$ and $\mathrm{SiHa}$ ) respectively.

Figure 1.Cytotoxicity assay against HeLa cell line. (A) Cytotoxicity graph at 24h, (B).Cytotoxicity graph at $48 \mathrm{~h},(\mathrm{C})$. Cytotoxicity graph at $72 \mathrm{~h}$. Data are representative as a mean $\pm \mathrm{SEM}$ of three independent experiments indicates $* \mathrm{p}<0.05, * * \mathrm{p}<0.01, * * * \mathrm{p}<0.001$ as compared to control.

Figure 2.Cytotoxicity assay against SiHa and CaSki cell lines at $24 \mathrm{~h}$ (A) Cytotoxicity graph of CaSki cell line, (B) Cytotoxicity graph of $\mathrm{SiHa}$ cell line. Data are representative as a mean $\pm \mathrm{SEM}$ of three independent experiments indicates $* \mathrm{p}<0.05, * * \mathrm{p}<0.01, * * * \mathrm{p}<0.001$ as compared to control. 


\section{Study of morphological changes of HeLa cells by LBE under Phase contrast microscopy and Fluorescence Microscopy}

The cells, treated with various concentrations of LBE, and after $24 \mathrm{~h}$ cells, were examined under a phase contrast microscope for monitoring their morphology. Untreated cells (negative control) exhibited normal spindle shape and reached $90 \%$ confluency after $24 \mathrm{~h}$ culture. Cells, treated with 500 $\mu \mathrm{g} / \mathrm{ml}$ and $1000 \mu \mathrm{g} / \mathrm{ml}$ of LBE were round and shrunken and cell membrane blebbing were observed in cells treated with $1000 \mu \mathrm{g} / \mathrm{ml}$ of LBE (Fig.3A, B and C). DAPI staining under fluorescence microscopy showed that increase of concentration of LBE, the intensity of fluorescence increased and nuclear shrinkage, fragmentation, chromosome condensation and apoptotic bodies, and the number of apoptotic cells increased in compare to the negative control (Fig D, E and F).

Figure 3.Cell morphology of untreated and treated cells. (A). Untreated (negative) HeLa cell, (B). LBE treated cells $(500 \mu \mathrm{g} / \mathrm{ml}),(\mathrm{C})$. LBE treated cells $(1000 \mu \mathrm{g} / \mathrm{ml})$.Nuclear morphological study by DAPI staining of HeLa cells. (D) Untreated (negative) HeLa cell, (E). LBE treated cells (500 $\mu \mathrm{g} / \mathrm{ml}),(\mathrm{F})$. $\mathrm{LBE}$ treated cells $(1000 \mu \mathrm{g} / \mathrm{ml})$. Arrow indicates nuclear fragmentations

\section{Mitochondrial membrane potential assay}

Mitochondrial membrane potential, in situ, is an important indicator of mitochondrial function and dysfunction and the loss of mitochondrial transmembrane potential $(\Delta \Psi \mathrm{m})$ leading to damage of mitochondrial membrane is the main step for mitochondrion-dependent apoptotic pathway. HeLa cells were treated with the two optimum concentrations of LBE such as $250 \mu \mathrm{g} / \mathrm{ml}$ in $6 \mathrm{~h}$ (Fig.4D, E ,F) and in $12 \mathrm{~h}$ (Fig.5D, E, F) and $500 \mu \mathrm{g} / \mathrm{ml}$ in $6 \mathrm{~h}$ (Fig.4G, H, I) and in $12 \mathrm{~h}$ (Fig.5G, H ,I) in vitro with compare to the control (Fig.4A, B, C;) Fig. 5A, B, C) and we examined the effect of LBE on inverted fluorescence microscopy (Olympus, Japan) by $\mathrm{JC1}$ retention as compared with negative control counterparts and it showed that LBE treatment significantly reduced JC1 fluorescence in HeLa cells, suggesting that the mitochondrial pathway is involved in LBE-induced apoptosis. In addition to that we also studied it by flow cytometry (FACS Calibri BD), and the (Fig.6A, B, C, D, E, F, G) showed that LBE disrupted and did dysfunction of mitochondrial transmembrane potential.

Figure 4\&5. Microscopic image of MMP by JC1 staining in HeLa cell line. Untreated (negative) HeLa cells (A) (aggregate), (B) (monomeric), (C) (merged). Treated cells (250 $\mu \mathrm{g} / \mathrm{ml})$ (D) (aggregate), (E) (monomeric),(F) (merged) and treated cells $(500 \mu \mathrm{g} / \mathrm{ml})(\mathrm{G})$ (aggregate) (H) (monomeric) (I) (merged) Indicate LBE induced time and concentration dependent mitochondrial membrane potential changes (Red to green fluorescence shift) in $6 \mathrm{~h}$ and $12 \mathrm{~h}$

Figure 6.Flowcytometric data on mitochondrial membrane potential changes in HeLa cells. (A) Untreated (negative) cells. (B) CCP treated. (C) Cisplatin $(50 \mu \mathrm{g} / \mathrm{ml})$. Treated cells (D, E, F, G), graph (\% apoptotic cells).Data are representative as a mean \pm SEM of three independent experiments indicates $* \mathrm{p}<0.05, * * \mathrm{p}<0.01, * * * \mathrm{p}<0.001$ as compared to control

\section{Intra cellular ROS generation assay}


To investigate the intracellular levels of ROS, the cell-permeable probe $\mathrm{H}_{2}$ DCFDA was utilized. Nonfluorescent $\mathrm{H}_{2}$ DCFDA, which is hydrolyzed to DCFH inside the cells, yields highly fluorescent DCFDA in the presence of intracellular $\mathrm{H}_{2} \mathrm{O}_{2}$ and associated peroxides. Whether or not $\mathrm{LBE}$ increased or decreased the generation of ROS was subsequently examined. As shown in (Fig.7), LBE treatment (500, $750 \mu \mathrm{g} / \mathrm{ml}$ ) increased the generation of ROS in HeLa cells, as determined by monitoring DCF fluorescence, when the dose of LBE was gradually increased. Also we studied ROS by FACS (Fig. 8)

Figure 7.Detection of ROS using carboxy $-\mathrm{H}_{2}$ DCFDA dye. HeLa cells were treated with $\mathrm{H}_{2} \mathrm{O}_{2}$ were compared to negative control cells. ROS induces the modification of carboxy- $\mathrm{H}_{2} \mathrm{DCFDA}$ that fluoresces green as detected by flow cytometry, the fluorescent peak in $\mathrm{H}_{2} \mathrm{O}_{2}$ treated cells shift compared to the peaks in controls $\left(\mathrm{H}_{2} \mathrm{O}_{2}\right.$ treated cells stained with oxidation insensitive dye and non-treated cells stained with carboxy- $\left.\mathrm{H}_{2} \mathrm{DCFDA}\right)$. Results confirm the presence of ROS in treated cells.

Figure 8. Flow cytometry data of intracellular ROS generation.Control (Negative) (A), $\mathrm{H}_{2} \mathrm{O}_{2}$ (B), Ascorbic acid (C), treated (D, E, F).Percentage of ROS generation graph (G). Data are representative as a mean \pm SEM of three independent experiments indicates $* p<0.05, * * p<0.01, * * * p<0.001$ as compared to control.

\section{Cell cycle distribution}

We study the cell cycle distribution of HeLa cells in FACS using PI staining. With the treatment of LBE proportion of the cell in the $\mathrm{G}_{2} / \mathrm{M}$ region increased as a dosage dependent and time dependent manner. The $\mathrm{G}_{2} / \mathrm{M}$ population of HeLa cell in vitro increase from $16.11 \%$ (control), to $19.55 \%(100 \mu \mathrm{g} / \mathrm{ml})$, $20.21 \%(250 \mu \mathrm{g} / \mathrm{ml})$, and $20.62 \%(500 \mu \mathrm{g} / \mathrm{ml})$ respectively in $6 \mathrm{~h}$ time duration (Fig.9A, B, C, D, E) In addition to $12 \mathrm{~h}$ time duration the HeLa cell was arrested in $\mathrm{G}_{2} / \mathrm{M}$ phase $17.62 \%(100 \mu \mathrm{g} / \mathrm{ml}), 17.64 \%$ $(250 \mu \mathrm{g} / \mathrm{ml})$, and $20.04 \%(500 \mu \mathrm{g} / \mathrm{ml})$ with compared to the control 16.87\% (Fig. 10A, B, C, D, E).

Figure $9 \& 10$. (A) Control (negative).(B, C, D \&E) LBE interferes with cell cycle population by inducing $\mathrm{G} 2 / \mathrm{M}$ arrest of HeLa cell in vitro, in $6 \mathrm{~h}$ and $12 \mathrm{~h}$.

\section{Annexin-V assay}

In annexin-V assay four different phenotypes were observed. (1) V-/PI/- (lower left quadrant) indicated as variable cells. (2) V+/PI/- (lower right quadrant), usually estimated as apoptotic cells.(3) V/PI/+(Upper left quadrant) showed necrotic cells and (4) $\mathrm{V}+/ \mathrm{PI} /+$ (upper right quadrant) indicated as a late apoptotic cells. The treatment of LBE increased in the population of apoptotic cells was observed with a concomitant decrease in the percentage of viable cells. Compared to the negative control V+/PI/cells increased $7.09 \%, 13.5 \%$ and $18.1 \%$ respectively by the treatment of 250,500 and $750 \mu \mathrm{g} / \mathrm{ml}$ (Fig.11A, C, D, ) respectively, where as in $1000 \mu \mathrm{g} / \mathrm{ml}$ showed V+/PI/+ cells $62.77 \%$ in $24 \mathrm{~h}$ (Fig 11E).

Figure 11.Annexin-V Assay in HeLa cells in vitro by FACS. (A) Control (Negative) cells. (B, C, D, \& E) treated cells. Quadrants: lower left: live cells; lower right: apoptotic cells; upper right: late apoptotic cells; and upper left: necrotic cells. Bar diagram representation of mean percentages cells in each of the abovementioned quadrants from different experimental groups are also given. Data are representative as a mean \pm SEM of three independent experiments indicates $* p<0.05, * * p<0.01, * * * p<0.001$ as compared to control. 


\section{DNA fragmentation assay}

DNA fragmentation of HeLa cells treated with $\operatorname{LBE}(500,750$ and $1000 \mu \mathrm{g} / \mathrm{ml})$ is easily detected as DNA laddering is prominent in agarose gel electrophoresis (Fig12). Increase of concentration of LBE increased the laddering.

Figure12. DNA ladder assay. Genomic DNA from HeLa cells was isolated and subjected to electrophoresis in agarose gel (1.8\%) and Control (C) lane showed no fragmented DNA but 1000 $\mu \mathrm{g} / \mathrm{ml}$ showed fragmented DNA in the form of ladder after $24 \mathrm{~h}$ DNA fragments were visualized under a UV trans-illuminator and compared with a standard marker.

\section{Induction of Autophagy by LBE}

Recently autophagy has gained much attention as the potent alternative mechanism to fight cancer. In fact autophagy is a self-digestive process of cells within auto phagosomes, and is delivered to the lysosome for subsequent degradation and recycling. In our autophagy experiment analyzed by FACS, autophagic cell distribution in negative control was $11.57 \%$ (Fig. 13D). It was increased to13.02\% (Fig.13F) and 26.76\% (Fig.13E) in $250 \mu \mathrm{g} / \mathrm{ml}$ and $500 \mu \mathrm{g} / \mathrm{ml}$ respectively. Our result was also validated by fluorescent microscopic analysis. In negative control, acidic vacuole was not present (Fig.13A), while it was increased with increasing concentrations (Fig.13B, C).

Figure 13.Autophagy of LBE treated in HeLa cell. Fluorescence microscopic image of autophagic cells (A) Negative control, (B \&C) treated. (D). Untreated (negative) cells, (E \& F).Treated cells, (G).graph (\% autophagic cells. Data are representative as a mean \pm SEM of three independent experiments indicates $* \mathrm{p}<0.05, * * \mathrm{p}<0.01, * * * \mathrm{p}<0.001$ as compared to control.

\section{F-actin staining}

F acting staining under Laser scanning confocal microscope showed that untreated (negative control) cells had no de polymerization in cytoskeleton and DAPI staining also showed the untreated cells are normal and no changes in cytoskeleton. In control (negative) there was no depolymerization of cytoplasmic F-actin. (14B, C). The treated cells with LBE $(750 \mu \mathrm{g} / \mathrm{ml})$ showed that cells are circular and de polymerization of F-actin filaments (14E). Nuclear DAPI staining showed distinct nucleus in case of control (14A), while treated nuclei were condensed and fragmented (14D, F).

Figure 14.F-actin analysis by confocal microscopy of LBE treated HeLa cell. Control (negative): (A) (DAPI), (B). (F-actin), and (C). (Merged). Treated: (D). (DAPI), (E). (F actin), and (F) (Merged). 


\section{Cancer stem cell population study by Hoechst efflux assay}

The Hoechst efflux assay was done by flow cytometer The Side Population(SP) tail contains cells that are able to efflux the Hoechst 33342 dye, The SP of HeLa cells in negative controls was $68.04 \%$ (15A) , while in LBE treatment, SP of HeLa cells was $46.34 \%$ in $250 \mu \mathrm{g} / \mathrm{ml}(15 \mathrm{~B}),, 20.81 \% 500 \mu \mathrm{g} / \mathrm{ml}$ (15C), respectively. Verapamil (positive control) treated HeLa cells showed $2.10 \%$ of SP in $50 \mu \mathrm{g} / \mathrm{ml}$ (15D) .Percentage of side population was also presented in bar diagram (1E).

Figure 15.Flow cytometry profiling of stem cell side population. (A). Control (negative), (B\&C). Treated (D), Positive control (E). Bar diagram (\% of stem cell side population).

\section{Study of induction of apoptosis by protein expression in Western blotting assay}

In order to understand how LBE induced apoptosis of cancer cells and inhibited cell proliferation, the gene expressions of pro- and anti-apoptotic genes such as, pro-caspase 3, pro-Caspase 9, P53, PARP and Bcl-2, were detected. We found that treatment with LBE decreased the expression of gene, procaspase 3, pro- caspase 9, Bcl-2 and PARP (Fig.16) in HeLa cells in vitro. More over p53 gene, one of important cancer guard genes showed high expression i.e. up regulated by LBE.

Figure 16. (A) Western immunoblot analysis. Alteration in the expression of p53 pro- caspase 3 procaspase 9 BcL-2 and PRAP: Equal loading of protein in the lanes was confirmed by beta actin.

\section{Anti-migration by LBE against HeLa cells by wound healing /scratch assay}

Cell migration was an important property of cancer cells. The effect of LBE on cell migration was examined by a wound healing or scratch assay in vitro (Fig 17). Cells were cultured in agarose plates $24 \mathrm{~h}$ to come $80 \%$ confluency. Cells in the plates were scratched by a $200 \mu \mathrm{l}$ pipette tip in the center of the well and exposed with various concentrations of LBE. Briefly, 50x103 HeLa cell per well were cultured in 24 well plate. After reaching $90 \%$ confluency, the center of the culture dishes was scratched with $200 \mu \mathrm{l}$ pipette tip. Then the cells were washed frequently by using PBS and incubated with LBE at concentration of 0,500 and $1000 \mu \mathrm{g} / \mathrm{ml}$. After $24 \mathrm{~h}$ image of the cells was taken under $10 \mathrm{X}$ magnification.

Figure 17.Effect LBE on migration of HeLa Cells in scratch method. (A) No cell migration in control (negative) at $0 \mathrm{~h}$. (B) Cell migration in control at $24 \mathrm{~h}$. Treated cell $0 \mathrm{~h}(\mathrm{C}, \mathrm{E})$ and $24 \mathrm{~h}(\mathrm{D}, \mathrm{F})$.

\section{Cologenic assay}


We tried to examine the capacity of the LBE to inhibit the colony formation of HeLa cells on agarose plate. The results showed maximum colony formation of HeLa cells in control (negative) (18A) where as in treatment, LBE decreased the colony formation of this cancer cells gradually when we increased doses from $250 \mu \mathrm{g} / \mathrm{ml}$ to $1250 \mu \mathrm{g} / \mathrm{ml}(18 \mathrm{~B}, \mathrm{C}, \mathrm{D}, \mathrm{E} \& \mathrm{~F})$ and in maximum dose $1250 \mu \mathrm{g} / \mathrm{ml}(18 \mathrm{~F})$ no cells were found in $24 \mathrm{~h}$. Treatment. The property of anchorage-independent growth of cancer cells, in vitro is one of the important properties, and colony formation is correlated with the in vivo oncogenic potential of cancer cells.

Figure 18.Effect of LBE on colony formation of HeLa cells in vitro. (A) Control (negative). Treated (B, C, D, E, and F): dose dependent inhibition of clonogenicity in HeLa cell

\section{Antitumor effects of LBE treatment in HeLa-implanted mice}

Growth of the tumors in HeLa cell-implanted mice is shown in (Fig19), and tumor growth (volume) in $50 \mathrm{mg} / \mathrm{kg}$ LBE treatment groups were plotted in line plot (Fig.20). Tumors in the HeLa + vehicle group increased in volume after 7 days $\left(0.65 \pm 0.10 \mathrm{~cm}^{3}\right)$, reaching a maximum of $4.10 \pm 1.59 \mathrm{~cm}^{3}$ after 28 days. The tumor volume for the $50 \mathrm{mg} / \mathrm{kg}$ LBE treatment groups on days $11,15,21$, and 28 were $0.49 \pm$ $0.07,0.23 \pm 0.05,0.14 \pm 0.03$, and $0.04 \pm 0.01 \mathrm{~cm}^{3}$, respectively (Table 1). When the weight of the tumors in this group was measured on day 28, following the sacrifice of the mice, the tumors were of the minimum weight $(214 \pm 12.34 \mathrm{mg})$, whereas, in the HeLa + vehicle control group (negative), the tumors attained the maximum volume $\left(4.10 \pm 1.59 \mathrm{~cm}^{3}\right)$. Treatment with $50 \mathrm{mg} \mathrm{LBE} / \mathrm{kg}$ of body weight of mice led to a marked reduction in the volume $\left(93.22 \pm 9.2 \% \mathrm{~cm}^{3}\right)$ and weight $(90.42 \pm 9.55 \%)$ of the tumors. However, the reduction of tumor volume in the HeLa + LBE 10 treatment group $(3.95 \pm 2.00$ $\mathrm{cm} 3)$ did not reach a significant level compared with the HeLa+ vehicle group $\left(4.10 \pm 1.59 \mathrm{~cm}^{3}\right)$. The visceral organs (kidney, liver, spleen, and lungs) were morphologically observed, and they were revealed to be normal and intact: No disorganization, no lesions and no abnormal growth were identified.

Figure 19. Effects of LBE on tumor growth on HeLa implanted mice. LBE suppresses the growth of cervical cancer tumors in swiss albino mice. Mice were inoculated subcutaneously in the right flank with $2 \times 10^{6} \mathrm{HeLa}$ cells. Tumor volume was measured twice/week using a caliper and calculated as (width) $)^{2} \times$ length $/ 2$. Representative images were captured at the end of therapy, (A) shows control mice (B) Tumor bearing mice, (C) measurement of tumor treated (LBE $10 \mathrm{mg} / \mathrm{kg}$ body weight), (D) measurement of tumor treated ( LBE $50 \mathrm{mg} / \mathrm{kg}$ body weight), (E) sacrificed mouse (dissected), (F) tumor dissection from sacrificed mice.

Figure 20.Graphical representation (line plot) of the effects of LBE on tumor growth (volume) in vivo. $\mathrm{mg} / \mathrm{kg}$ indicates $\mathrm{mg}$ LBE per $\mathrm{kg}$ body weight of mice. The data represented as mean $\pm \mathrm{SD}$ for the three different experiments performed in triplicate. Error bars of $\pm \mathrm{SD}$ are inserted in figure 
Table 1 Tumor progression and reduction in volume and percentage of reduction at various doses ( $\mathrm{mg}$ /Kg body weight of mice) of LBE

\begin{tabular}{|c|c|c|c|c|}
\hline \multirow{2}{*}{$\begin{array}{l}\text { Treatment No. of } \\
\text { ( Day) }\end{array}$} & \multicolumn{4}{|c|}{ Tumor volume in $\mathrm{cm}^{3} \pm \mathrm{SD}$} \\
\hline & $\begin{array}{l}\text { HeLa+vehicle } \\
\text { Group }\end{array}$ & $\begin{array}{l}10 \mathrm{mg} \mathrm{LBE} / \mathrm{Kg} \\
\text { Group }\end{array}$ & $\begin{array}{l}25 \mathrm{mg} \text { LBE } / \mathrm{Kg} \\
\text { Group }\end{array}$ & $\begin{array}{l}50 \mathrm{mg} \quad \mathrm{LBE} / \mathrm{Kg} \\
\text { Group }\end{array}$ \\
\hline 1st(after7days) & $0.65 \pm 0.10$ & $0.71 \pm 0.12$ & $\begin{array}{l}0.75 \pm 0.09 \\
*(0.0)\end{array}$ & $\begin{array}{l}0.59 \pm 0.09 \\
(0.0)\end{array}$ \\
\hline $2^{\text {nd }}\left(11^{\text {th }}\right.$ Day $)$ & $2.03 \pm 0.15$ & $0.97 \pm 0.15$ & $\begin{array}{l}0.65 \pm 0.10 \\
(13.33 \pm 2.12)\end{array}$ & $\begin{array}{l}0.49 \pm 0.07 \\
(16.94 \pm 2.52)\end{array}$ \\
\hline $3 \mathrm{rd}\left(15^{\text {th }}\right.$ Day $)$ & $3.02 \pm 1.00$ & $2.17 \pm 1.15$ & $\begin{array}{l}0.55 \pm 0.10 \\
(26.66 \pm 3.23)\end{array}$ & $\begin{array}{l}0.23 \pm 0.05 \\
(61.01 \pm 4.34)\end{array}$ \\
\hline $4^{\text {th }}\left(21^{\text {st }}\right.$ Day $)$ & $3.57 \pm 1.30$ & $3.19 \pm 1.00$ & $\begin{array}{l}0.45 \pm 0.05 \\
(40 \pm 3.90)\end{array}$ & $\begin{array}{l}0.14 \pm 0.03 \\
(76.27 \pm 6.12)\end{array}$ \\
\hline $5^{\text {th }}\left(28^{\text {th }}\right.$ Day $)$ & $4.10 \pm 1.59$ & $3.95 \pm 2.00$ & $\begin{array}{l}0.39 \pm 0.90 \\
(50 \pm 4.00)\end{array}$ & $\begin{array}{l}0.04 \pm 0.01 \\
(93.22 \pm 9.2)\end{array}$ \\
\hline
\end{tabular}

Note: *Data within parentheses indicate percentage $(\%)$ of tumor reduction or regression in volume. The calculation of percentage of reduction of tumor volume was done with respect to the tumor volume generated after 7 days of implantation of HeLa in $25 \mathrm{mg} \mathrm{LBE} / \mathrm{Kg}$ Group and 50mg LBE / Kg Group.

\section{Gas chromatography-mass spectrometry (GC-MS) analysis}

GC-MS analysis is powerful tool for qualitative and quantitative analysis of various compounds present in natural products. And widely being applied in medical, biological and food research ${ }^{34-37}$. In 
present study the GC-MS analysis of the LBE of L. betulina from the NIST inbuilt, Library Data Bank showed the presence of 69 compounds (Fig 21). Of the 69 compounds obtained, 32 compounds had the higher matching probability above $50 \%$ with the standard compounds of the NIST Library data Bank (Table 1). Out of which, 14 compounds found to be in higher proportion with the percentage peak area $>1$. Two of the 14 compounds 9,12-Octadecadienoic acid (Z,Z)( Mwt :280.452 g/mol, Chemical formula $: \underline{\mathrm{C}}_{18} \underline{\mathrm{H}}_{32} \underline{\mathrm{O}}_{2}$ ) and Ergosta-5,8,22-trien-3-ol, (3.beta22E) (Mwt: 396.6484 and Chemical formula: $\left.\mathrm{C}_{28} \mathrm{H}_{44} \mathrm{O}\right)$. Were in a significantly higher proportion with the percentage peak area 22.13 and 19.72 respectively.Next compounds with their \% peak area are Tetradecanoic acid ( 9.87, saturated fatty acid ), Linoleic acid ethyl ester ( 6.43, polyunsaturated), Oleic acid (4.37, 2.42, monounsaturated fatty acid); Hexadecanoic acid, 2-hydroxy-1-(hydroxymethyl) ethylester (2.31 Cyclooctacosane (1.38, saturated fatty acid); Phenol, 2,4-bis (1,1-dimethylethyl) (1.50), Phenol, 2,4,6-tris (16icycle[2.2.1]hept2-yl), and 4'-Hydroxy-6-methoxyaurone (1.34). Lupeol, which is also present in LBE, is a natural pentacyclic triterpenoid (Table2).

Table 2 Compounds with quality /probability greater than $50 \%$, their retention time (RT) and $\%$ of peak area in GS-MS

\begin{tabular}{|c|c|c|c|c|}
\hline No & $\mathrm{RT}$ & Quality/Probablity & $\begin{array}{c}\% \text { of peak } \\
\text { Area }\end{array}$ & Compound \\
\hline 1 & 5.254 & 74 & 0.27 & Hexylene Glycol \\
\hline 2 & 14.589 & 56 & 0.47 & $\begin{array}{c}2-(2- \\
\text { Hydroxyethyl)piperidine }\end{array}$ \\
\hline 3 & 15.616 & 94 & 1.50 & $\begin{array}{l}\text { Phenol, 2,4-bis(1,1- } \\
\text { dimethylethyl) }\end{array}$ \\
\hline 4 & 16.342 & 50 & 0.13 & Dodecanoic acid \\
\hline 5 & 16.898 & 95 & 0.34 & Diethyl Phthalate \\
\hline 6 & 19.160 & 96 & 0.39 & Tetradecanoic acid \\
\hline 7 & 19.570 & 97 & 0.22 & 5-Octadecene, (E)- \\
\hline 8 & 20.545 & 93 & 1.23 & Pentadecanoic acid \\
\hline 9 & 21.038 & 78 & 0.22 & $\begin{array}{c}\text { Tetradecanoic acid, ethyl } \\
\text { ester }\end{array}$ \\
\hline 10 & 21.578 & 78 & 0.35 & $\begin{array}{l}\text { Hexadecanoic acid, methyl } \\
\text { ester }\end{array}$ \\
\hline 11 & 21.889 & 58 & 0.40 & 4-Undecene, $(\mathrm{E})$ \\
\hline 12 & 22.304 & 97 & 9.87 & Tetradecanoic acid \\
\hline 13 & 22.792 & 98 & 2.00 & $\begin{array}{c}\text { Hexadecanoic acid, ethyl } \\
\text { ester }\end{array}$ \\
\hline
\end{tabular}




\begin{tabular}{|c|c|c|c|c|}
\hline 14 & 23.638 & 76 & 0.50 & $\begin{array}{l}\text { Hexadecadienoic acid, } \\
\text { methyl ester }\end{array}$ \\
\hline 15 & 24.016 & 93 & 0.59 & Heptadecanoic acid \\
\hline 16 & 24.592 & 81 & 0.22 & $\begin{array}{l}\text { Heptadecanoic acid, ethyl } \\
\text { ester }\end{array}$ \\
\hline 17 & 25.459 & 98 & 22.13 & $\begin{array}{c}\text { 9,12-Octadecadienoic acid } \\
(\mathrm{Z}, \mathrm{Z})\end{array}$ \\
\hline 18 & 25.516 & 93 & 4.37 & Oleic Acid \\
\hline 19 & 25.563 & 92 & 2.42 & Oleic Acid \\
\hline 20 & 25.832 & 99 & 6.43 & Linoleic acid ethyl ester \\
\hline 21 & 25.921 & 95 & 1.21 & Ethyl Oleate \\
\hline 22 & 26.367 & 96 & 0.38 & $\begin{array}{l}\text { Octadecanoic acid, ethyl } \\
\text { ester }\end{array}$ \\
\hline 23 & 31.628 & 90 & 2.31 & $\begin{array}{c}\text { Hexadecanoic acid, 2- } \\
\text { hydroxy-1- } \\
\text { (hydroxymethyl)ethyl ester }\end{array}$ \\
\hline 24 & 32.266 & 80 & 0.58 & $\begin{array}{l}\text { 1,2-Benzenedicarboxylic } \\
\text { acid, diisooctyl ester }\end{array}$ \\
\hline 25 & 34.373 & 97 & 2.86 & $\begin{array}{c}\text { 9,12-Octadecadienoic acid } \\
(\mathrm{Z}, \mathrm{Z})\end{array}$ \\
\hline 26 & 34.773 & 64 & 0.50 & $\begin{array}{c}\text { Octadecanoic acid, 2- } \\
\text { hydroxy-1- } \\
\text { (hydroxymethyl)ethyl ester }\end{array}$ \\
\hline 27 & 35.333 & 55 & 01.34 & $\begin{array}{l}\text { 4'-Hydroxy-6- } \\
\text { methoxyaurone }\end{array}$ \\
\hline 28 & 36.391 & 70 & 0.59 & $\begin{array}{c}\text { 2,6,10-Dodecatrien-1-ol, } \\
\text { 3,7,11-tr }\end{array}$ \\
\hline 29 & 37.725 & 78 & 1.38 & Cyclooctacosane \\
\hline 30 & 38.711 & 52 & 0.90 & $\begin{array}{c}\text { Phenol, } 2,4,6- \\
\text { tris(17icycle[2.2.1]hept-2- } \\
\text { yl)- }\end{array}$ \\
\hline 31 & 41.134 & 90 & 0.23 & $\begin{array}{c}\text { Stannane, } \\
\text { dibutylcyclohexylmethyl }\end{array}$ \\
\hline
\end{tabular}




\begin{tabular}{|c|c|c|c|c|}
\hline 32 & 41.549 & 91 & 19.72 & $\begin{array}{c}\text { Ergosta-5,8,22-trien-3-ol, } \\
\text { (3.beta22E) }\end{array}$ \\
\hline
\end{tabular}

\section{DISCUSSION}

The current findings demonstrated that LBE of L. betulina is very potent killer of HeLa, CaSki and $\mathrm{SiHa}$ as validated by MTT assay, and present elaborate experimental works on various parameters such as inhibition of proliferation, induction of apoptosis, reduction of mitochondrial membrane potential, generation of intracellular ROS, induction of autophagy of HeLa cell line, de-polymerization of Factin of cytoplasm, cancer stem cell population study and anti-metastatic assay (migration and cologenic assay) were not conducted by any other worker but previously extracts of different mushrooms on other cell lines were reported by other scientists. As per the report of Liu et al. ${ }^{36}$, the EE of L.betulina displayed strong anticancer activity against cancer cell line MDA-MB-231, with $\mathrm{IC}_{50}$ value of $51.46 \mu \mathrm{g} / \mathrm{ml}$, and there was $83.15 \%$ inhibition at a concentration of $200 \mu \mathrm{g} / \mathrm{ml}$ (MTT assay). Before that Oyetayo ${ }^{8}$ evaluated the hex-anolic (LHE), ethyl acetate (LEA) and ethanol (LET) extracts of $L$. betulina for cytotoxic effect (\%) against some cancer cell lines such as U251 (glioblastoma), PC-3 (prostatic adenocarcinoma), K562 (chronic myelogenous leukemia), HCT-15 (colorectal adenocarcinoma), MCF-7 (breast cancer cell line) and SKLU-1 (lung adenocarcinoma). In our experiment of MTT assay against HeLa cells, LBE showed $70 \%$ inhibition and $\mathrm{IC}_{50}$ was $492.52 \pm 0.56 \mu$ $\mathrm{g} / \mathrm{ml}$. In our previous experiments ${ }^{38} \mathrm{LBE}(\mathrm{EE})$ and $\mathrm{ml} \mathrm{LBE}(\mathrm{ME})$ in the concentration of $1250 \mu \mathrm{g} / \mathrm{ml}$ showed $83.61 \pm 9.98$ and $72.44 \pm 5.78 \%$ of CaSki cell inhibition after $24 \mathrm{~h}$ and the IC50 values of these extracts against CaSki were 220 and $490 \mu \mathrm{g} / \mathrm{ml}$ respectively. The $\mathrm{IC}_{50}$ values of water extract (WE) and $\mathrm{ME}$ of Calocybe indica in $\mathrm{MHH}-\mathrm{ES}$ - 1 cell line were $55.25 \pm 1.201 \mathrm{mg} / \mathrm{ml}$ and $46.56 \pm 0.134 \mathrm{mg} / \mathrm{ml}$ respectively while these values of MCF7 cell line were $52.12 \pm 0.15 \mathrm{mg} / \mathrm{ml}$ and $47.94 \pm 0.09 \mathrm{mg} / \mathrm{ml}$ respectively ${ }^{39}$. The $\mathrm{IC}_{50}$ values of EE of Phellinus igniarius at $48 \mathrm{~h}$ were 72 and 103 $\mu \mathrm{g} / \mathrm{ml}$ for SK-Hep-1 cells and RHE cells, respectively ${ }^{39}$. Recently Wu et al. ${ }^{40}$ investigated that the ethanol extract of $F$. pinicola showed stronger inhibitory effect on cancer cells than water extract. Several workers reported chromatin condensation and DNA fragmentation of different cancer cells by different mushroom extracts such as EAC extract $(10 \mathrm{~g} / \mathrm{ml})$ of Cyathus striatus treatment on HPAF- 
II and PL45 cells ${ }^{41}$, the extract of Agaricus blazei against leukemia NB-4 and K-562 cells ${ }^{42}$, and extract of A. bisporus on CaSki cells after $48 \mathrm{~h}$ treatment ${ }^{38}$. Treatment of COLO-205 cells with of three mushrooms (Auricularia polytricha, Macrolepiota procera and Pleurotus ostreatus) revealed the characteristic pattern of DNA laddering on agarose gel electrophoresis ${ }^{43}$. Our DNA laddering assay result is corroborated with other's results.

Apoptosis, a genetically regulated form of cell death, plays an important role in homeostasis condition in our body ${ }^{44}$. Its defects can contribute to diseases like cancer, so interest surrounding the apoptosis has grown highly among oncologists. Apoptosis is suggested to be one of the major modes of action of chemotherapeutic anti-cancer drugs on malignant cells ${ }^{45}$, 46 ; there are two types of pathways in apoptosis i.e. the extrinsic pathway and the intrinsic mitochondria-mediated pathway. This induction of apoptosis was coupled with generation of reactive oxygen species (ROS), mitochondrial dysfunction, activation of caspases, and cleavage of poly (ADP-ribose) polymerase protein ${ }^{47}$. No mechanistic study has been conducted to investigate anti-cancer mechanism of LBE of L. betulina mushrooms by any previous authors. For the first time, in our study LBE of this mushroom showed the very promising anticancer effect by inducing apoptosis through ROS generation, reduction of $\mathrm{MMP}, \mathrm{P}^{53}$ up regulation and $\mathrm{Bcl} 2$, pro- caspase-3,pro- caspase 9 and PRAP down regulation. But EE of other mushrooms such as Pleurotus ferue on B16F10 (melanoma), BGC 823 (gastric cancer) and the immortalized human gastric epithelial mucosa cell line GES-1 ${ }^{48}$. Comparison of the effects of extracellular, intracellular polysaccharides, and ethanol extracts of Tremella mesenterica revealed that only ethanol extract triggered apoptosis in A549 cells. Such effect was happened by activating a mitochondrial pathway: reduction of mitochondrial Trans membrane potential, the production of ROS (reactive oxygen species), and the activation of caspase-3 protein in ethanol extract-treated A549 cells $\mathrm{s}^{49}$. The effects of ethanol extracts of other mushrooms on many cancer cell lines for inhibition of cell proliferation and expression of cleaved-caspase 3 and PARP, were recorded ${ }^{50,51,40 .}$

According to $\mathrm{Xue}^{50}$, the intra-cellular ROS generation in cancer cells by agents is an important phenomenon in cancer management. Available literatures show the anti-proliferative effects of intracellular ROS against cancer cells. As per the results of experiment conducted ${ }^{52}$, in ALVA-41 and PC-3 prostate cancer cells, intracellular ROS increased caspase-3 activity and cytochrome- c secreting from mitochondria trigger apoptosis. Induction of intracellular ROS by drugs e.g. cisplatin, and paclitaxel has been used to treat cancers that have high ROS status themselves ${ }^{50,53-55}$. Xue ${ }^{50}$ observed dramatically increased levels of extra- and intra-cellular ROS in LNCaP cells within $3 \mathrm{~h}$ of BBEA treatment and it triggered apoptosis. In our experiment treated cells showed higher intracellular ROS formation in contrast to untreated cells. Our results regarding ROS formations are at per with others finding but in different cell line by different mushroom extract. No scientist observed the intracellular ROS production by EE of LB in HeLa cell lines. Cell cycle analysis demonstrated that, LBE arrested cell cycle at G2/M checkpoint of HeLa cells it was also supported by our previous work where cycle was arrested at the $\mathrm{G}_{2} / \mathrm{M}$ checkpoint by EE of Pluerotus florida ${ }^{56}$. Similarly Jiang \& Silva ${ }^{57}$, observed that methanolic extract of MC(mycocomplex) induced significant cell cycle arrest at G2/M phase. Moreover, cell cycle arrest at G2/M was induced by A. blazei in gastric epithethelial cells ${ }^{58}$ where as methanolic extract of Pleurotus ostreatus induced cell cycle arrest at G0/G1 of breast cancer (MDAMB-231 and MCF-7) and of colon cancer cells (HCT-116 and HT-29) ${ }^{59}$. Similarly Wang et al ${ }^{60}$ found LBE of $P$. ferulae arrested cell cycle of melanoma cancer B16F10 cells at G0/G1. Interestingly, different extract from $G$. lucidum demonstrate specific effects on cell cycle progression. Thus, extracts from G. lucidum blocked cell cycle at $\mathrm{G} 0 / \mathrm{G} 1$ check point in breast cancer cells ${ }^{61-63}$. Whereas arrest at $\mathrm{G} 2 / \mathrm{M}$ phase was induced in prostate ${ }^{62}$, hepatoma ${ }^{64}$ and bladder cancer cells ${ }^{65}$. On the other hand, Dudhgaonkar et al. ${ }^{66}$ isolated triterpenes from G. lucidum and observed that they triggered cell cycle 
arrest at G0/G1 and G2/M phase in macrophages; therefore it suggested that cell cycle arrest depends on the specific biologically active compounds as well as particular cells.

We also examined activity of the LBE as anti-metastasis by performing cologenic assay and antimigration assay against HeLa cell line. Ganoderic acids (GA-A and GA-H) from Ganoderma lucidum demonstrated inhibition on colony formation of invasive breast cancer cells ${ }^{67}$. Pleurotus ostreatus (aqueous extract) exhibited a reduction in the number of colonies of COLO-205 (oral cancer) cells with $43.8 \pm 3.5 \%$ in contrast with $100 \%$ proliferation on untreated cells ${ }^{68}$. Our Cologenic assay also showed anti colonization property as indicated by other workers in other cell line. The migration property of cancer cells is another hall mark of metastasis. In our migration scratch assay, LBE showed very good anti migration agent against HeLa cell line. It was also supported by $\mathrm{F}$ actin filament polymerization caused by LBE in our Laser Scanning Confocal microscopy (LSCM) study. Actin polymerization status as measured by an increase in F/G-actin ratio (increased F-actin or decreased G-actin), is a marker of cancer ${ }^{69}$. Our current experiment showed that cytoplasmic F-G actin was depolymerized by LBE in HeLa cells as seen under LSC Microscopy. Lu et al. ${ }^{65}$ observed that Ganoderma extracts (ethanolic) triggered anti proliferation, arrested cell cycle at $\mathrm{G} 2 / \mathrm{M}$, and induced actin polymerization in bladder cancer cells and mentioned the impact of actin polymerization in cell migration. Since actin polymerization is a cell cycle-related event ${ }^{70}$, we may infer that the observed inhibition of cell proliferation and arrest in G2/M check point and inhibition of cell migration by LBE in HeLa cells may be linked with actin remodeling. However, to draw the exact relationships between actin remodeling, $G$ 2/M arrest, and growth inhibition need more elaborated research. As we know, cytoplasmic actin filament forms podia of HeLa cells by which cells migrate and their polymerization/ shrinkage invariably inhibits podia extension and migration.

Recently autophagy has gained much attention as the potent alternative mechanism to fight cancer. Although the impact of autophagy on cancer cell death is a topic of intense debate ${ }^{71,72}$, one school of oncologists with their data supports the alternate mechanism of autophagy in the death of cancer cells 73-75. There are emerging evidences that autophagy, a caspase-independent cell death process, plays critical roles in the generation of antineoplastic responses and mediates caspase-independent malignant cell death ${ }^{76}$. Other scientists studied that the deletion of Atgs and Bif-1(autophagy-regulating genes) also validated that autophagy suppressed tumor functions ${ }^{77},{ }^{78}$. We examined first that LBE also induced autophagy on the HeLa cell that is caspase independent cell death process. Curcumin triggered the occurrence of autophagy in SUP-B15 cells at exact $4 \mathrm{~h}$ and $8 \mathrm{~h}$ after treatment of it ${ }^{79}$. Similarly, we infer that in addition to apoptosis, autophagy is another mechanism of LBE to inhibit the proliferation of HeLa cell line and tumerogenesis in mice as supported from finding of Santi et $a l^{74}$ who recorded that metformin prevents cell tumorigenesis through autophagy-related cell death.

Currently analysis of cancer stem cell has gained impetus in therapeutic study, as whether therapeutic strategy is able to kill all cancer stem cells (CTC) in tumor or not. Otherwise cancer/tumor will relapse after time being. So population of cancer stem cell analysis is new addition in cancer biology. We also estimated the population of stem cell of HeLa after treatment by LBE and our results showed that treatment of LBE significantly reduced CTC population after the time. A study of mice in vivo with implanted BGC-823 cancer cells revealed that the weight and volume of the tumors were reduced after 15 days' treatment with $P$. ostreatus mycelium polysaccharide 2 (POMP2) ${ }^{80}$. In another study, polysaccharides were extracted from Lepista sordida, and when applied against laryngo carcinoma, these inhibited cell growth in vitro and caused a reduction in tumor size in vivo ${ }^{81}$ The 
compound ergosterol was isolated from Agaricus brasiliensis, and led to a retardation in tumor growth in sarcoma 180-bearing mice. In studies in vivo, ergosterol was shown to inhibit neovascularization, as well as being potentially an inhibitor of angiogenesis ${ }^{82}$ A marked reduction in tumor fluid volume, and changes in various other properties, were identified in Dalton's lymphoma ascites-bearing mice following Calocybe indica (milky mushroom) treatment, in comparison with negative control group mice $^{83}$ In the present study, $50 \mathrm{mg} \mathrm{LBE} / \mathrm{kg}$ body weight of mice also led to a marked reduction in tumor volume in HeLa cell-implanted mice. None of the previous study found mechanistic clue of compounds exist in EE of mushrooms. GC-MS profile of LBE exhibited that out of 69, 14 compounds were in higher proportion with the percentage peak area $>1$. Two of the 14 compounds, 9, 12Octadecadienoic acid (Z, Z) and Ergosta-5, 8, 22-trien-3-ol, (3.beta22E) were in a significantly higher proportion with the percentage peak area 22.13 and 19.72 respectively. We started to search data base (Swiss target prediction, www. Swisstarget pridiction. ch ) to find out the binding affinity cites of these two compounds. We found that Ergosta-5, 8, 22-trien-3-ol, (3. beta22E) has maximum binding affinity to Cytochrome P 450 of mitochondria, so it can attach with later and induces it for further regulation of caspase 9 apoptotic gene. Similarly, 9, 12-Octadecadienoic acid $(Z, Z)$ has affinity to bind with fatty acid binding protein of membrane, peroxisome proliferator activated receptor, and tyrosyl DNA phosphodiesterase. The ergo sterol of Amauroderma rude, when injected in murine cancer infected mice, enhanced survival time of the mices, indicating that ergosterol might be the leading anticancer substance ${ }^{84}$.The inhibitors of COX-1 and COX-2 enzymes are the compounds - ergosterol, ergosta4,6,85, 22 -tetraen-3-one and 1-oleoyl-2-linoleoyl-3-palmitoylglicerol were isolated from Grifola frondosa ${ }^{86,22}$. In our LBE has much \% of peak area of Ergosterol, so it conferred anti HeLa. In LBE another important fatty acid compound N-hexadecanoic acid is present and it showed significant cytotoxicity against human colorectal carcinoma cells (HCT-116) ${ }^{87}$. Harada et al. ${ }^{87},{ }^{88}$ reported that $\mathrm{N}$ hexadecanoicacid blocked proliferation of human fibroblast cells by inhibiting DNA topoisomerase-I. Lai et al ${ }^{89}$ reported that it binds to microtubule associated protein 'tau', and inhibits cell division. Other workers demonstrated that both oleic and $\alpha$-linolenic acid showed a proliferation inhibition effect on prostate carcinoma cells ${ }^{90,91}$. More over phenolic compounds such as Phenol, 2,4-bis(1,1dimethylethyl) (1.50) and Phenol, 2,4,6-tris (21icycle[2.2.1]h ept-2-yl) are also found in LBE. Role of phenolic compounds as anticancer is now well established. A recent study showed that 2, 4-bis (1,1dimethylethyl)- (1) is cytotoxicity against Hela cell ${ }^{92}$. Mechanistic studies have shown that phenolic compounds can produce reactive oxygen species (ROS) under cell culture conditions and induce apoptosis in cancer cells ${ }^{93-98}$. It has been reported that polyphenolic compounds have inhibitory effects on mutagenesis and carcinogenesis in humans, when up to $1.0 \mathrm{gm}$ is ingested daily from a diet rich in fruits and vegetables ${ }^{99}$.Only four phenolic acids, however, were analyzed in Agaricus (white \&brown) and shiitake mushrooms ${ }^{100}$. In our experiment LBE showed potent anti proliferative property with $\mathrm{IC}_{50}$ at $492.52 \pm 2.6 \mu \mathrm{g} / \mathrm{ml}, 612.22 \pm 4.2 \mu \mathrm{g} / \mathrm{ml}$, and $1210.30 \pm 6.4 \mu \mathrm{g} / \mathrm{ml}$ for $24 \mathrm{~h}$ against HeLa, CaSki and $\mathrm{SiHa}$ cell line respectively. Liu et al. ${ }^{101}$ isolated eight compounds including 5 sterols from L. betulina, while Fakoya \& Oloketuyi ${ }^{9}$, reported phenolic and steroids compounds are present in EE of this mushroom. Lupeol, one terpenoid, is also present in LBE, library search exhibited that it facilitated significant inhibition of growth of breast cancer cell line ${ }^{102}$, prostate ${ }^{103}$, colorectal $^{104}$, and gastric cancer $^{105}$. GCMS profile of LBE also showed the presence of 4'-Hydroxy-6-methoxyaurone and this compound inhibits cancer cells to acquire drug resistant and also cytotoxicity against mouse RAW264.7 cell ${ }^{106}$. Recently multidrug resistance (MDR) of tumor cells to cytotoxic drugs is a major problem in cancer chemotherapy ${ }^{106}$. It has been well established that the mechanism by which tumor cells acquire multidrug resistance (MDR) is the over expression of aPgp (P-glycoprotein: ATP dependent membrane glycoprotein) that binds a drug and drags out it from the cell ${ }^{107-109}$. The driving force of drug efflux is Pgp-mediated ATP hydrolysis, the liberated energy of which is used for the drug 
transport ${ }^{110-112}$. 4-Hydroxy-6-methoxyaurone has high binding affinity to the nucleotide-binding domain of $\mathrm{Pgp}^{113}$ and by binding with Pgp it may inhibit the cancer cells to become drug resistant. ${ }^{112}$

In conclusion, LBE (LBE of L.betulina) is a mixture of potential compounds for inhibition of proliferation of HeLa, CaSki and SiHa cell lines. By apoptosis as shown by ROS generation, MMP reduction, regulating pro-caspase $3 \& 9$, and cancer guard gene p53, it was found that LBE is potent anti-HeLa cell line. Moreover it induced caspase independent autophagy of HeLa cells and prevents tumerogenesis. It blocked the cell division by arresting G2/M checkpoint. Anti-metastasis property of it was also revealed from anti-migration and anti-cologenic capacity. Its anti-migration property was also validated from F-G actin polymerization capacity in HeLa cells. Efficacy to reduce cancer stem cell population is one another important anti-HeLa property of this mushroom. Antitumor effects of LBE treatment in HeLa-implanted mice model, in our experiment also validated that LBE is one important anti cervical cancer activity. GC-MS profile also exhibited a lot of anti-cancerous fatty acids, phenol and terpenoid. One interesting compound i.e. 4'-Hydroxy-6-methoxyaurone which inhibits the cancer cells to become drug resistant. Taken together, the anticancer activity of ethanol extract of $L$. betulina may be the result of the synergistic effects of various compounds, which suggests that this mushroom is excellent source of anticancer agents in the treatment of cervical cancer.

\section{REFERENCES}

1. Beluhan S. Ranogajec A (2011) Chemical composition and non-volatile components of Croatian wild edible mushrooms. Food Chem 124: 1076-1082.

2. Cheung PCK (2010) The nutritional and health benefits of mushrooms. Nutrition Bulletin35: 292299.

3. Cheung LM, Cheung PCK, Ooi VEC (2003). Antioxidant activity and total phenolics of edible mushroom extracts. Food Chem 81: 249-255.

4. Barros L, Cruz T, Baptista P, Estevinho LM, Ferreira ICFR (2008) .Wild and commercial mushrooms as source of nutrients and nutraceuticals. Food Chemistry Toxicology 46: 2742-2747.

5. Barros L, Dueñas M, Ferreira I(2009) Phenolic acids determination by HPLC-DAD- ESI/MS in sixteen different Portuguese wild mushrooms species. Food and Chemical 2009, 47, 1076-1079.

6. Wasser SP (2011). Current findings, future trends, and unsolved problems in studies of medicinal mushrooms. Appl Microbiol Biotechnol89: 1323-1332.

7. Christensen CM (1972). Common edible mushrooms. Minneapolis: University of Minnesota Press.

8. Oyetayo VO (2009). Free radical scavenging and antimicrobial properties of extracts of wild mushrooms.Braz J Microbiol 40(2):380-6. 
9. Fakoya S, Oloketuyi SF (2012). Antimicrobial efficacy and phytochemical screening of mushrooms, Lenzites betulina and Coriolopsisgallica extracts. TAF Prev Med Bull11 (6): 695-8.

10.Teplyakova TV, Psurtseva NV, Kosogova TA, Mazurkova NA, Khanin VA, Vlasenko VA (2012). Antiviral activity of polyporoid mushrooms (higher Basidiomycetes) from Altai Mountains (Russia). Int J Med Mushrooms14 (1): 37-45

11. Fujimoto H, Nakayama M, Nakayama Y, Yamazaki M (1994). Isolation and characterization of immuno suppressive components of three mushrooms,Pisolithustinctorius, MicroporusflabellaformisandLenzitesbetulina. Chem Pharm Bull (Tokyo) 42(3): 694-7

12.Israilidesa C, Kletsasb D, Arapogloua D, Philippoussisc A, Pratsinisb H, Ebringerova' d A, $\mathrm{Hr}^{2} 1^{\prime}$ balova' e,v SE(2008). Harding In vitro cytostatic and immunomodulatory properties of the medicinal mushroom Lentinula edodes.Phytomedicine15: 512-519

13. Ivanova TS, Krupodorova TA, Barshteyn, V.Y, Artamonov AB, Shlyakhovenko VA (2014). Anticancer Substances of Mushroom Origin. ExpOncol 36 ( 2): 58-66.

14.Siegel RL, Miller KD, Jemal ADVM, (2017) Cancer statistics, 2017 CA: A Cancer Journal for Clinicians 67(1):07-30

15. Anantharaman VV, Sudharshini S, Chaitra A (2013). A cross-sectional study on knowledge, attitude, and practice on cervical cancer and screening among female health care providers of Chennai corporation. J AcadMedSci2:124-8.

16. Narayana G, Suchitra MJ, Sunanda G, Ramaiah JD, Kumar BP, Veerabhadrappa KV (2017 )Knowledge, attitude, and practice toward cervical cancer among women attending Obstetrics and Gynecology Department: A cross sectional, hospital-based survey in South India. Indian J Cancer $54: 481-7$

17. ICO Information Centre on HPV and cancer. Human Papillomavirus and Related Diseases in India (Summary Report 2014-08-22); 2014

18. Karmaker R, Bandyapadhya A, Barui, Maiti PK, Battacharya A, Choudhury MK (2010) Pattern of cancer occurrence in rural population of West Bengal--a hospital-based study.J Indian Med Assoc. 108(8):505-6, 508.

19. Baindara P, AnkurGautam, G. P. S. Raghava\& Suresh Korpole (2017). Anticancer properties of a defensin like class IIdbacteriocin Laterosporulin10 Scientific Report 7:46541 DOI:10.1038/srep46541

20. Hoskin DW, AyyalusamyRamamoorthy(2008). Studies on anticancer activities of antimicrobial peptides.BiochimicaetBiophysicaActa 1778:357 - 37 
21.Qiao J, Liu J , Jia K, Li N, Liu B, Zhang Q, Zhu R(2016). Diosmetin triggers cell apoptosis by

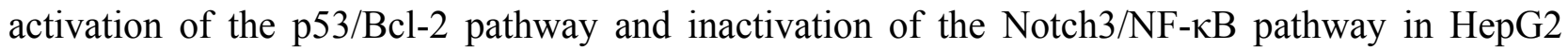
cells Oncology Letters12: 5122-5128

22.Zhang J-J, Li Y, Zhou T, Dong-Ping Xu D-P , Zhang P, Li S and Li H-B (2016) Bioactivities and Health Benefits of Mushrooms Mainly from China Molecules21: 938; doi:10.3390/molecules21070938 www.mdpi.com/journal/molecule.

23. Shin, Kim AJ, Lim SY, Kim G, SungMK, Lee ES, Ro J. (2010). Dietary mushroom intake and the risk of breast cancer based on hormone receptor status, Nutr. Cancer, 62:4, 476-483.

24. Lucas, E. H. (1957). Tumor inhibition in Boletus edulis and other Holobasidiomycetes. Antibiotic Chemotherapy, 7, 1-15.

25. Ikekawa T, Uehara N, Maeda Y, Nakanishi M, Fukuoka F(1969). Antitumor activity of aqueous extracts of edible mushrooms. Cancer Res29: 734-735.

26. Wasser SP (2002). Medicinal mushrooms as a source of antitumor and immune modulating polysaccharides. Appl. Microbiol. Biot 60: 258-274.

27.Mizuno $\mathrm{T}$ (1999). The extraction and development of antitumor active polysaccharides from medicinal mushrooms in Japan (review) Int. J. Med. Mushr1: 9-30.

28.Mo S, Wang S, Zhou G, Yang Y, Li Y, Chen X, et al. (2004). Cytotoxic pyrano[4,3c][2]benzopyran-1,6-dione and furo[3,2-c]pyran-4-one derivatives from the fungus Phellinus igniarius. J Nat Prod 67:823-828.

29.Dai Yu-C, Yang Z-L, Cui B-K, et al.(2009).Species diversity and utilization of medicinal mushrooms and fungi in China (review). Int J Med Mush11: 287-302.

30.Watling R (1973). Identification of the Larger Fungi. Hulton,Amersham

31. Pacioni, G. (1981). Guide to Mushrooms edited: Gary L Simon \& Schuster Inc. New York, 1981, p.51 I

32. http://www.mycobank.org/mb/292246

33. Freshney RI. Culture of Animal Cells. A Manual for Basic Technique, 2000, 4th ed. Wiley-liss, Ajohuwiley and Sons. Inc.Publication, New York.

34. Ribeiro VLS, Toigo E, Bordignon SAL, Gonçalves K, von Poser G (2007) Acaricidal properties of extracts from the aerial parts of Hypericum polyanthemum on the cattle tick Boophilus microplus. Vet Parasitol 147:199-203

35. Suseem SR, Mary SaralAa , Reddy NP, Gregory M (2011) Evaluation of the analgesic activity of ethyl acetate, methanol and aqueous extracts of Pleurotus mushroom Asian Pacific Journal of Tropical Medicine 4: 117-120 
36. Liu K, Wang JL, Zhao L, Wang Q (2011). Anticancer and antimicrobial activities and chemical composition of the birch maze gill mushroom Lenzites betulina (higher Basidiomycetes). Int J Med Mushrooms16 (4):327-37.

37. Song QT-Y, Lin H-C, Yang N-C, Hu M-L (2008). Anti- proliferativeandanti-metastatic effects of the LBEof Phellinus igniarius (Linnearus: Fries). J Ethnopharmacol115:50-56

38. Ghosh SK, Sanayal T and Chakrabarty AM 2019 Anti-proliferative and Apoptotic Effect Of Ethanolic and MLBEof Edible Mushroom Agaricus Bisporus Against CaSki Cell Line of Cervical Cancer. plant Cell Biotechnology And Molecular Biology 19(7\&8):372-382;

39. Ghosh SK. Study of anticancer effect of Calocybe indica mushroom on breast cancer cell line and human Ewings sarcoma cancer cell lines. N Y Sci J 2015;8(5):10-15]. (ISSN: 15540200).http://www.sciencepub.net/newyork.

40. Wu H-T, Lu FH, Su Y-C, Ou H-Y, Hung H-C, Wu J-S, (2014). In Vivo and In Vitro AntiTumor Effects of Fungal Extracts Molecules, 19:2546-2556.

41. Fares F, Shait L, Wasser SP (2011). Extracts of cyathusstriatus mushrooms, pharmaceutical compositions comprising them and a new cyathusstriatus strain,8th Dec2011 Patent No: WO

2011151831

A1

42. Kim C-F, Jiang J-J, Leung K-N, Fung K-P, B-S Lau C (2009). Inhibitory effects of Agaricusblazei extracts on human myeloid leukemia cells. J Ethnopharmacol122:320-326

43. Arora S, Tandon S(2015). Mushroom extracts induce human colon cancer cell (COLO-205) death by triggering the mitochondrial apoptosis pathway and Go/G1-phase cell cycle arrest. Arch Iran Med18(5):284 - 295.

44. Kerr J F R, Wyllie A H, Currie A R (1972). Apoptosis: A Basic Biological Phenomenon with Wideranging Implications in Tissue Kinetics, 26:239-257.

45. Sellers WR, Fisher DE (1999). Apoptosis and cancer drug targeting. J Clin Invest104:1655-61.

46. Frankfurt OS, Krishan A (2003). Apoptosis enzyme-linked immunosorbent assay distinguishes anti-cancer drugs from toxic chemicals and predicts drugsynergism. ChemBiol Interact 2003;145:89-99.

47. Jeong J-W, Jin C-Y, Park C, Hong SH, Kim G-Y, Jeong YK, Lee J-D, Yoo YH, Choi YH (2011). Induction of apoptosis by cordycepin via reactive oxygen species generation in human leukemia cells. ToxicolIn Vitro25:817-824.

48. Wang W, Chen K, Liu Q, Johnston N, Ma Z, et al. (2014). Suppression of Tumor Growth by Pleurotus ferulae Ethanol Extract through Induction of Cell Apoptosis, and Inhibition of Cell Proliferation and Migration. PLOS ONE9(7): e102673. doi:10.1371/journal.pone.0102673

49. Chen N-Y, Lai H-H, Hsu T-H, et al.(2008).Induction of apoptosis in human lung carcinoma A549 epithelial cells with an ethanol extract of Tremella mesenterica. Bioscience Biotech Biochem72: 1283-9.

50. Xue T (2013) Anti-Cancer Effects Of Phenolic-Richextracts of Button Mushrooms (Agaricusbisporus) PhD Thesis, Department of Food Science The Graduate School, The Pennsylvania State University, USA.

51. Hseu Y-C, Chen S-C, Tsai P-C, Chen C-S, Lu F-J, Chang NW, Yang H-L (2007). Inhibition of cyclooxygenase-2 and induction of apoptosis in estrogen-nonresponsive breast cancer cells by Antrodiacamphorata. Food Chem Toxicol45:1107-1115.

52. Ahmad K A, Wang G, Ahmed K (2006). Intracellular hydrogen peroxide production is an upstream event in apoptosis induced by down-regulation of casein kinase 2 in prostate cancer cells. Molecular cancer research 4: 331-338. 
53. Jing Y, Dai J, Chalmers-Redman RM, Tatton W G, Waxman S(1999). Arsenic trioxide selectively induces acute promyelocytic leukemia cell apoptosis via a hydrogen peroxidedependent pathway. Blood 94: 2102-2111.

54. Alexandre J, Nicco C, Chéreau C, Laurent A, Weill B, Goldwasser F, et al.(2006). Improvement of the therapeutic index of anti cancer drugs by the superoxide dismutase mimic mangafodipir. Journal of The National Cancer Institute 98: 236-244.

55. López-Lázaro M (2007). Dual role of hydrogen peroxide in cancer: possible relevance to cancer chemoprevention and therapy. Cancer Letters 252: 1-8.

56. Ghosh SK, Sanayal T, Mahato T, Pal S and Chakrabarty AM Anti-proliferative, apoptotic, antimigratory and anti-colonization effects of LBEof Pleurotus florida on HeLa cells, and its antitumor effect on HeLa-implanted mice Inter. J. of Oncology (in press) 2019.

57. JiangJ, Silva D (2010). Novel medicinal mushroom blend suppresses growth and invasiveness of human breast cancer cells In J. of Oncology37: 1529-1536.

58. Jin C.Y, Choi YH, Moon D-O, Park C, Ark Y-I, Jeong S-C et al (2006). Induction of G2/M arrest and apoptosis in human gastric epithelial AGS cells by aqueous extract of Agaricus blazei Oncology Reports 16: 1349-1355.

59. Jedinak A, SlivaD(2008).Pleurotus ostreatus inhibits proliferation of human breast and colon cancer cells through p53-dependent as well as p53-independent pathway. Internationa Journal of Oncology 33: 1307-1313.

60. Wang W, Chen K, Liu Q, Johnston N, Ma Z, Zhang F, et al. (2014) Suppression of Tumor Growth by Pleurotus ferulae Ethanol Extract through Induction of Cell Apoptosis, and Inhibition of Cell Proliferation and Migration. PLoS ONE 9(7): e102673.

61. Hu H, Ahn NS, Yang X, Lee YS and Kang KS (2002): Ganodermalucidum extract induces cell cycle arrest and apoptosis in MCF-7 human breast cancer cell. Int J Cancer 102: 250-253.

62. Jiang J, Slivova V, Valachovicova T, Harvey K,Sliva D (2004). Ganodermaluciduminhibits proliferation and induces apoptosis in human prostate cancer cells PC-3. Int J Oncology 24(5):

63. Jiang J, Slivova V and Sliva D (2006.): Ganodermalucidum inhibits proliferation of human breast cancer cells by down-regulation of estrogen receptor and NF-kappaB signaling. Int $\mathrm{J}$ Oncol 29:695-703,

64. Lin SB, Li CH, Lee SS and Kan LS (2003). Triterpene-enriched extracts from Ganoderma lucidum inhibit growth of hepatoma cells via suppressing protein kinase $C$, activating mitogen- activated protein kinases and G2-phase cell cycle arrest. Life Sci.72: 2381-2390.

65. Lu QY, Jin YS, Zhang Q, Zhang Z, Heber D, Go VL, Li FP and Rao JY(2004). Ganodermalucidum extracts inhibit growth and induce actin polymerization in bladder cancer cells in vitro. Cancer Lett 216: 9-20.

66. Dudhgaonkar S, Thyagarajan A and SlivaD(2009). Suppression of the inflammatory response by triterpenes isolated from the mushroom Ganodermalucidum. Int Immunopharmaco19: 1272-1280.

67. Jiang J, Grieb B, Thyagarajan A, Sliva D ( 2008). Ganoderic acids suppress growth and invasive behavior of breast cancer cells by modulating AP-1 and NF- $\kappa$ B signaling .International Journal of Molecular Medicine 21: 577-584.

68. Arora Shagun, Tandon Simran,(2016). Mitochondrial pathway mediated apoptosis and cell cycle arrest triggered by aqueous extract of wheatgrass in colon cancer colo-205 cells. Journal of Plant Biochemistry and Biotechnology 25:56-63.

69. Han KY, Pantuck AJ, Belldegrun AS, Rao JY (2002). Tumor markers for the early detection of bladder cancer, Front Biosci 7 e19-e26. 
70. Rao JY, Hurst HE, BalesWD, Jones PL, Bass RA, Archer LT, et al.(1990) . Cellular Factin levels as a marker for cellular transformation: relationship to cell division and differentiation. Cancer Res 50: 2215-2220.

71. Marx J (2006) Autophagy: Is it cancer's friend or foe? Science312:1160-161.

72. Bhutia SK, Mukhopadhyay S, Sinha N, Das DN, Panda PK, Patra SK, et al.(2013). Autophagy: Cancer's friend or foe? Advanced Cancer Research118:61-95.

73. KulkarniYM, Kaushik V, Azad N, Wright C, RojanasakulY, O’Doherty G, et al. (2016). Autophagy-Induced Apoptosis in Lung Cancer Cells by a Novel Digitoxin AnalogJ Cell Physiol.231(4): 817-828.

74. Santi DM, Baldelli G, Diotallevi A, Galluzzi,L, Schiavano GF, Brandi G(2019) Metformin prevents cell tumorigenesis through autophagy-related cell death Scientific Reports 9, Article number: 66 (2019)

75. Sung B, Chung HY, Kim ND (2016). Role of Apigenin in Cancer Prevention via the Induction of Apoptosis and Autophagy. Journal of Cancer prevention 21(4):216-226.

76. Eisenberg-Lerne Avital, KimchAdi (2009). The paradox of autophagy and its implication in cancer etiology and therapy, Apoptosis 14, 376 -391.

77. Takahashi Y, Coppola D, Matsushita N, Cualing HD, Sun M, SatoY, et al.(2007). Bif-1 interacts with Beclin 1 through UVRAG and regulates autophagy and tumorigenesis. Nat Cell Bio 19:114251.

78. Mariño G, Salvador-Montoliu N, Fueyo A, Knecht E, Mizushima N, López-Otín C. (2007). Tissue-specific autophagy alterations and increased tumorigenesis in mice deficient in Atg4C/ autophagin-3. J BiolChem 282:18573-83.

79. Guo Y, Shan QQ, Gong PY, Wang SC(2018). The autophagy induced by curcumin via MEK/ERK pathway plays an early anti-leukemia role in human Philadelphia chromosome-positive acute lymphoblastic leukemia SUP-B15 cells. J Can Res Ther14:S125-31.

80. Cao X-Y, Liu J -L, Wei Yang, Hou X and Li Q-J Antitumor activity of polysaccharide extracted from Pleurotus ostreatus mycelia against gastric cancer in vitro and in vivo Molecular Medicine Reports 12: 2383-2389, 2015.

81. Miao S, Mao X, Pei R, et al Antitumor activity of polysaccharides from Lepista sordida against laryngo carcinoma in vitro and in vivo. Int J Biol Macromol 60: 235-240, 2013.

82. Takaku T, Kimura Y, Okuda H: Isolation of an antitumor compound from Agaricus blazei Murill and its mechanism of action. J Nutr 131: 1409-1413, 2001

83. Ganapathy $\mathrm{J}$ and Renitta E: Evaluation of Anti-Cancer Activity and Anti-Oxidant Status of Calocybe Indica (Milky Mushroom) On Dalton's Lymphoma Ascites Induced Mice. Aust J Basic \& Appl Sci 8(10): 466-475, 2014

84. Li XM, Wu QP, Xie YZ, Ding YR, Du WW, Sdiri M, Yang BB(2015). Ergosterol purified from medicinal mushroom Amauroderma rude inhibits cancer growth in vitro and in vivo by upregulating multiple tumor suppressors. Oncotarget6: 17832-17846.

85. Pujol V, Seux V, Villard J (1990). Research of antifungal substances secreted by higher fungi in culture. Ann. Pharm. Fr 48: 17-22.

86. Zaidman B, Yassin M, Mahajana J, Wasser SP (2005). Medicinal mushroom modulators of molecular targets as cancer therapeutics. Appl. Microbiol. Biotechnol. 67: 453-468.

87. Lokesh R Kannabiran K (2017). Cytotoxic potential of N-hexadecanoicacid extracted fromKigeliapinnata leaves. Asian J Cell Biol12: 20-27.

88. Harada H, Yamashita U, Kurihara H, Fukushi F, Kawaba ta J , Kamei Y( 2002). Antitumor activity of palmitic acid found as a selective cytotoxic substance in a marine red alga. 
89. Lai CS, Mas RH, Nair NK, Maji MI, Mansor SM, Navaratnam V(2008). Typhoniumflagelliforme inhibits cancer cell growth in vitro and induces apoptosis: an evaluation by the bioactivity guided approach. J Ethnopharmacol 118:14-20.

90. Hughes-Fulford M, Chen Y, Tjandrawinata RR (2001). Fatty acid regulates gene expression and growth of human prostate cancer PC-3 cells. Carcinogenesis 22 (5): 701-7.

91. Zeng L, Biernacka KM, Holly JM, Jarrett C, Morrison AA, Morgan A et al.(2010) Hyperglycaemia confers resistance to chemotherapy on breast cancer cells: the role of fatty acid synthase. EndocrRelatCancer17 (2): 539-51

92. Narendhran S, Rajiv P, Vanathi P, Sivaraj R (2014). Spectroscopic analysis of bioactive compounds from Streptomyces cavouresisKUV39: evaluation of antioxidant and cytotoxicity activity. Int J Pharm PharmSci 6:319-322.

93. Xue ZH, Li JM, Cheng AQ, Yu WC, Zhang ZJ, Kou XH, Zhou FJ(2015) Structure identification of triterpene from the mushroom Pleurotuseryngiiwith inhibitory effects against breast cancer. Plant Foods HumNutr70: 291-296.

94. Macho A., Blázquez M. V, Navas P., Muñoz E (1998). Induction of apoptosis by vanilloid compounds does not require de novo gene transcription and activator protein 1 activity. Cell Growth Differentiation, 9, 277-286.

95. Yang GY, Liao J, Li C, Chung J, Yurkow EJ, Ho CT, Y. C.(2000). Effect of black and green tea polyphenols on c-jun phosphorylation and $\mathrm{H}(2) \mathrm{O}(2)$ production in transformed and nontransformed human bronchial cell lines: possible mechanisms of cell growth inhibition and apoptosis induction. Carcinogenesis 21: 2035- 2039.

96. Lu TL, Huang GJ, Lu TJ, Wu JB, Wu CH, Yang TC, Iizuka A, Chen YF (2009) . Hispolon from Phellinus linteus has anti-proliferative effects via MDM2-recruited ERK1/2 activity in breast and bladder cancer cells. Food Chem Toxicol47:2013-2021

97. Chen W, He FY, Li YQ (2006). The apoptosis effect of hispolon from Phellinus linteus (Berkeley $\&$ Curtis) Teng on human epidermoid $\kappa \mathrm{B}$ cells. J Ethnopharmacol105:280-285.

98. Chen W, Zhao Z, Li L, Wu B, Chen SF, Zhou H, Wang Y, Li YQ(2008a). Hispolon induces apoptosis in human gastric cancer cells through a ROS-mediated mitochondrial pathway. Free Radic Biol Med 45:60-72.

99. SurhY(1999). Molecular mechanisms of chemopreventive effects of selected dietary and medicinal phenolic substances. Mutation Research428: 305-327.

100. Mattila P, KonkoK, Eurola M,Pihlava, JM, Astola J, VahteristoL.; Hietaniemi, V.; Kumpulainen, J.; Valtonen, M.; Piironen, V (2001). Contents of vitamins, mineral elements, and some phenolic compounds in cultivated mushrooms.Journal of Agricultural and Food Chemistry49:2343-2348.

101. Liu K, Wang JL, Gong WZ, Xiao X, Wang Q(2013). Antioxidant activities in vitro of ethanol extract and fractions from mushroom. Lenzitesbetulina. J Food Biochem37(6): 687-93.

102. Lambertini E, Lampronti I, Penolazzi L, Khan MT, Ather A, Giorgi G, et al.(2005) Expression of estrogen receptor alpha gene in breast cancer cells treated with transcription factor decoy is modulated by Bangladeshi natural plant extracts. Oncol Res15:69-79.

103. Siddique HR, Mishra SK, Karnes RJ, Saleem M. (2011). .Lupeol, a novel androgen receptor inhibitor: implications in prostate cancer therapy. Clin Cancer Res 17:5379-91.

104. Tarapore RS, Siddiqui IA, Adhami VM, Spiegelman VS, Mukhtar H.(2013) .The dietary terpene lupeol targets colorectal cancer cells with constitutively active Wnt/ $\beta$-catenin signaling. MolNutr Food Res 57:1950-1958.

105. Wu XT, Liu JQ, Lu XT, Chen FX, Zhou ZH, Wang T, et al.(2013). The enhanced effect of lupeol on the destruction of gastric cancer cells by NK cells. IntImmunopharmacol. 16:332-40. 
106. Gottesman M Michael, Pastan Ira (1993). Annual Review of Biochemistry 62, 385-427.

107. Juliano R L, Ling V (1976) A surface glycoprotein modulating drug permeability in Chinese hamster ovary cell mutants. BiochimicaetBiophysicaActa (BBA) -Biomembranes455, 152162).

108. Gros P, Croop J, Housman D (1986). Mammalian multidrug resistance gene: Complete cDNA Sequence indicates strong homology to bacterial transport proteins Cell 47: $371-380$.

109. Gerlach James H, Endicott Jane A, Juranka Peter F, Henderson Graham, Sarangi Farida, Deuchars Kathryn L, Ling Victor (1986) Homology between P-glycoprotein and a bacterial haemolysin transport protein suggests a model for multidrug resistance. Nature volume: 324, pages485-489.

110. Ford JM (1996) Experimental reversal of P-glycoprotein-mediated multidrug resistance by pharmacological chemosensitisers Eurropian Journal of Cancer, 32A, 991-1001.

111. Ashida H, Oonishi T, Uyesaka N (1998). Kinetic Analysis of the Mechanism of Action of theMultidrug Transporter Journal of Theorotical Biology 195: 219 —232

112. Wiese M, Pajeva IK (2001) Structure-Activity Relationships of Multidrug Resistance Reversers Current MeditionalChemistry8: 685—713.

113. Boumendjel A, Beney C, Deka N, Mariotte A-M, Lawson MA, Trompier D(2002). 4Hydroxy-6- methoxyaurones with High-Affinity Binding to Cytosolic Domain of P-Glycoprotein. Chem Pharm Bull50 (6): 854—856. 


\section{Acknowledgements}

Authors acknowledge National Test House, Kolkata for providing GC-MS facility and principle of Ramakrishna Mission Vivekananda Centenary College (Autonomous) for providing laboratory facilities. Authors are very grateful to Professor Ananda Mohan Chakrabarty for giving needful suggestion for designing of the research.

\section{Funding information}

Authors acknowledge the financial support from the Department of Science \& Biotechnology, GoWB, W.B., India. (No.840 (sanc)/ST/P/S\&T/1G-11/2015). The funders had no role in study design, data collection and analysis, decision to publish, or preparation of the manuscript.

\section{Author's contribution}

S.K.G. has done research design and written manuscript. T.S. has done experimental works, data collection and data analysis.

\section{Data availability statement}

All relevant data are within the manuscript

\section{Competing financial and nonfinancial interests}

Authors declare no competing financial and nonfinancial interest. 
Figure 1.

\section{HeLa cell line}
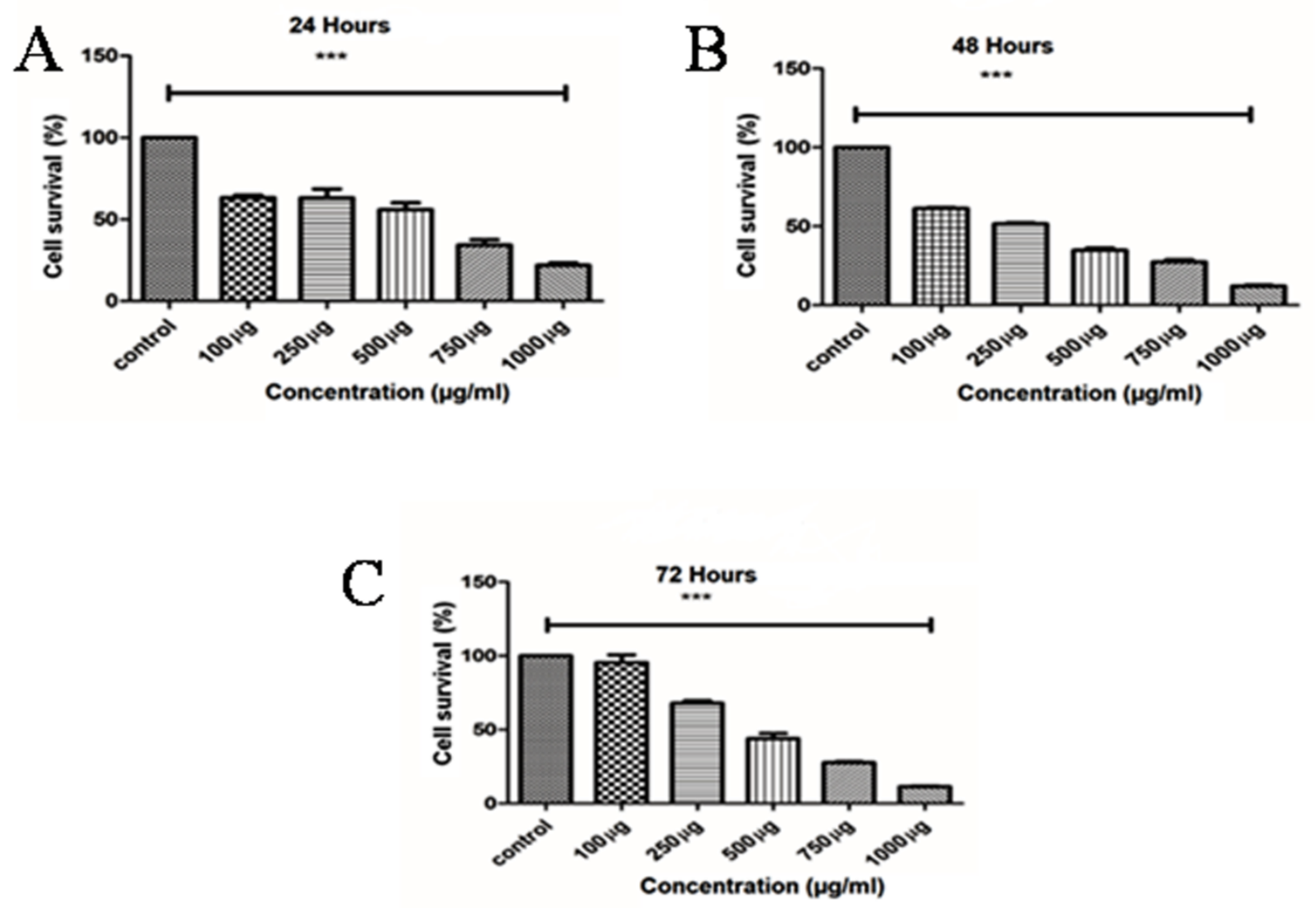

Figure 1.Cytotoxicity assay against HeLa cell line. (A) Cytotoxicity graph at 24h, (B).Cytotoxicity graph at $48 \mathrm{~h},(\mathrm{C})$. Cytotoxicity graph at $72 \mathrm{~h}$. Data are representative as a mean \pm SEM of three independent experiments indicates $* \mathrm{p}<0.05, * * \mathrm{p}<0.01, * * * \mathrm{p}<0.001$ as compared to control. 
Figure 2 .

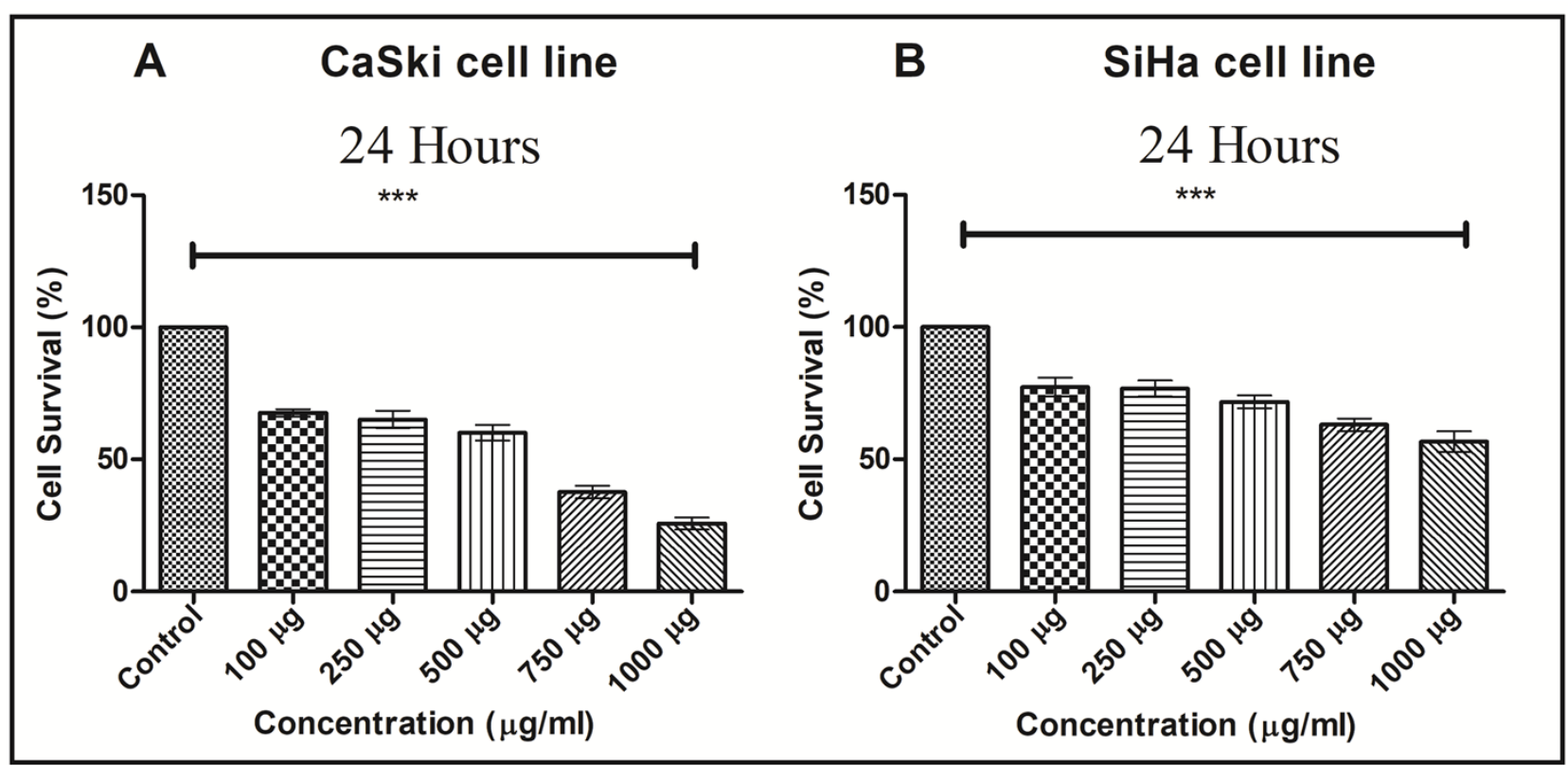

Figure 2.Cytotoxicity assay against SiHa and CaSki cell lines at $24 \mathrm{~h}$ (A) Cytotoxicity graph of CaSki cell line, (B) Cytotoxicity graph of $\mathrm{SiHa}$ cell line. Data are representative as a mean $\pm \mathrm{SEM}$ of three independent experiments indicates $* \mathrm{p}<0.05, * * \mathrm{p}<0.01, * * * \mathrm{p}<0.001$ as compared to control. 
Figure 3.

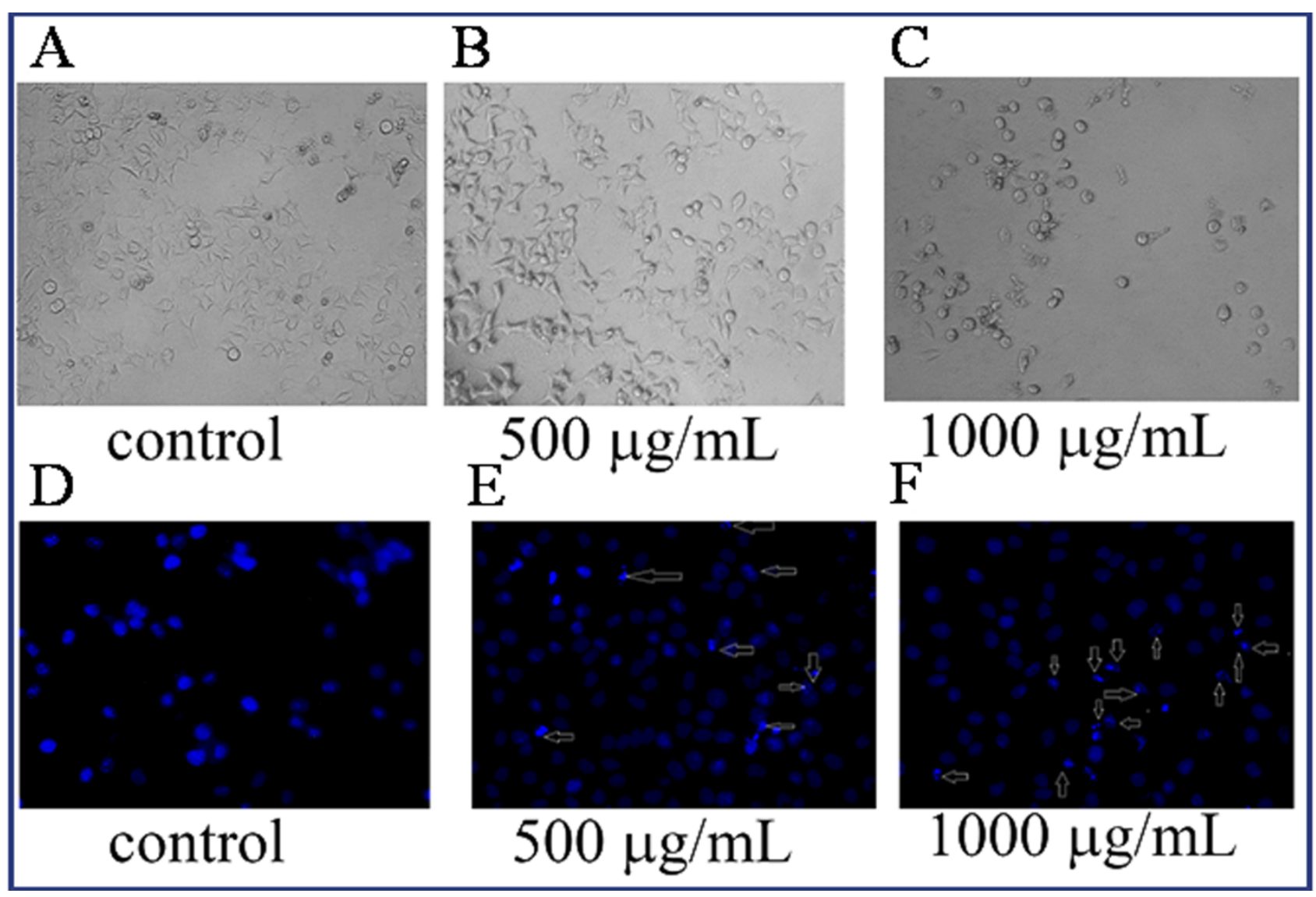

Figure 3.Cell morphology of untreated and treated cells. (A). Untreated (negative) HeLa cell, (B). LBE treated cells $(500 \mu \mathrm{g} / \mathrm{ml}),(\mathrm{C})$. LBE treated cells $(1000 \mu \mathrm{g} / \mathrm{ml})$.Nuclear morphological study by DAPI staining of HeLa cells. (D) Untreated (negative) HeLa cell, (E). LBE treated cells (500 $\mu \mathrm{g} / \mathrm{ml})$, (F). LBE treated cells $(1000 \mu \mathrm{g} / \mathrm{ml})$. Arrow indicates nuclear fragmentations.

Figure 4. 
bioRxiv preprint doi: https://doi.org/10.1101/540567; this version posted February 5, 2019. The copyright holder for this preprint (which was not certified by peer review) is the author/funder, who has granted bioRxiv a license to display the preprint in perpetuity. It is made available under aCC-BY 4.0 International license.

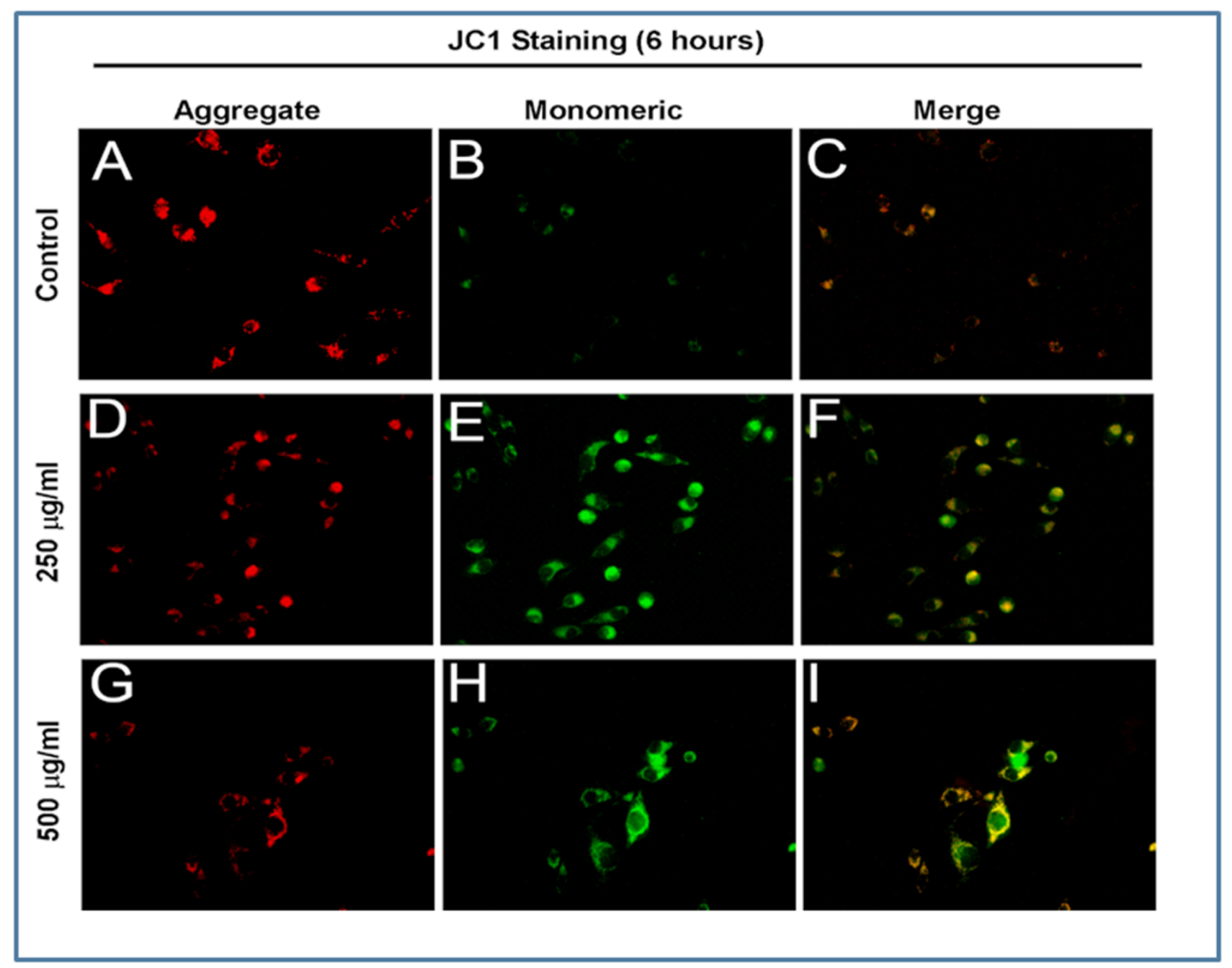

Figure 5. 


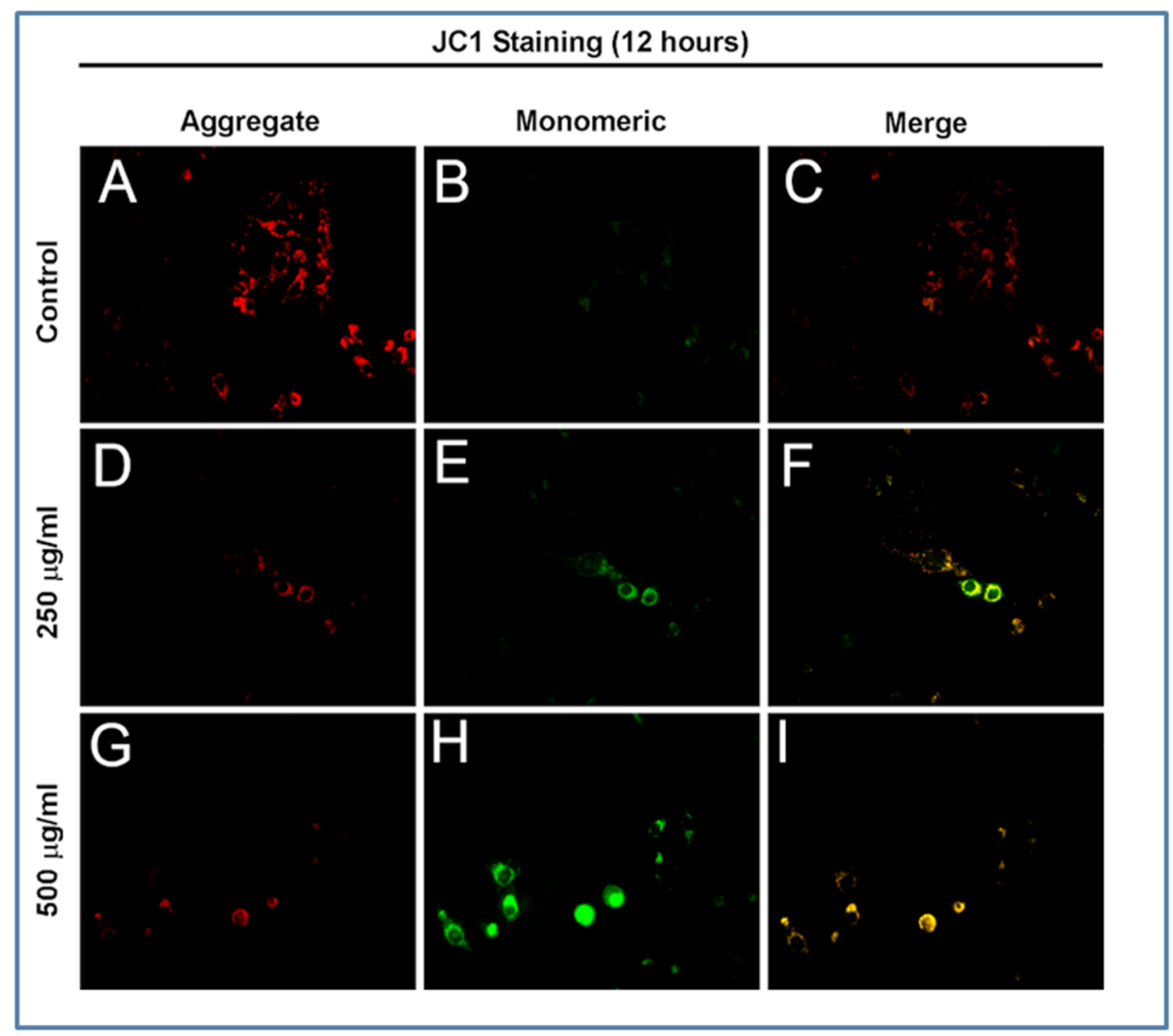

Figure 4\&5. Microscopic image of MMP by JC1 staining in HeLa cell line. Untreated (negative) HeLa cells (A) (aggregate), (B) (monomeric), (C) (merged). Treated cells (250 $\mu \mathrm{g} / \mathrm{ml})$ (D) (aggregate), (E) (monomeric),(F) (merged) and treated cells $(500 \mu \mathrm{g} / \mathrm{ml})$ (G) (aggregate) (H) (monomeric) (I) (merged) Indicate LBE induced time and concentration dependent mitochondrial membrane potential changes (Red to green fluorescence shift) in $6 \mathrm{~h}$ and $12 \mathrm{~h}$

Figure 6. 


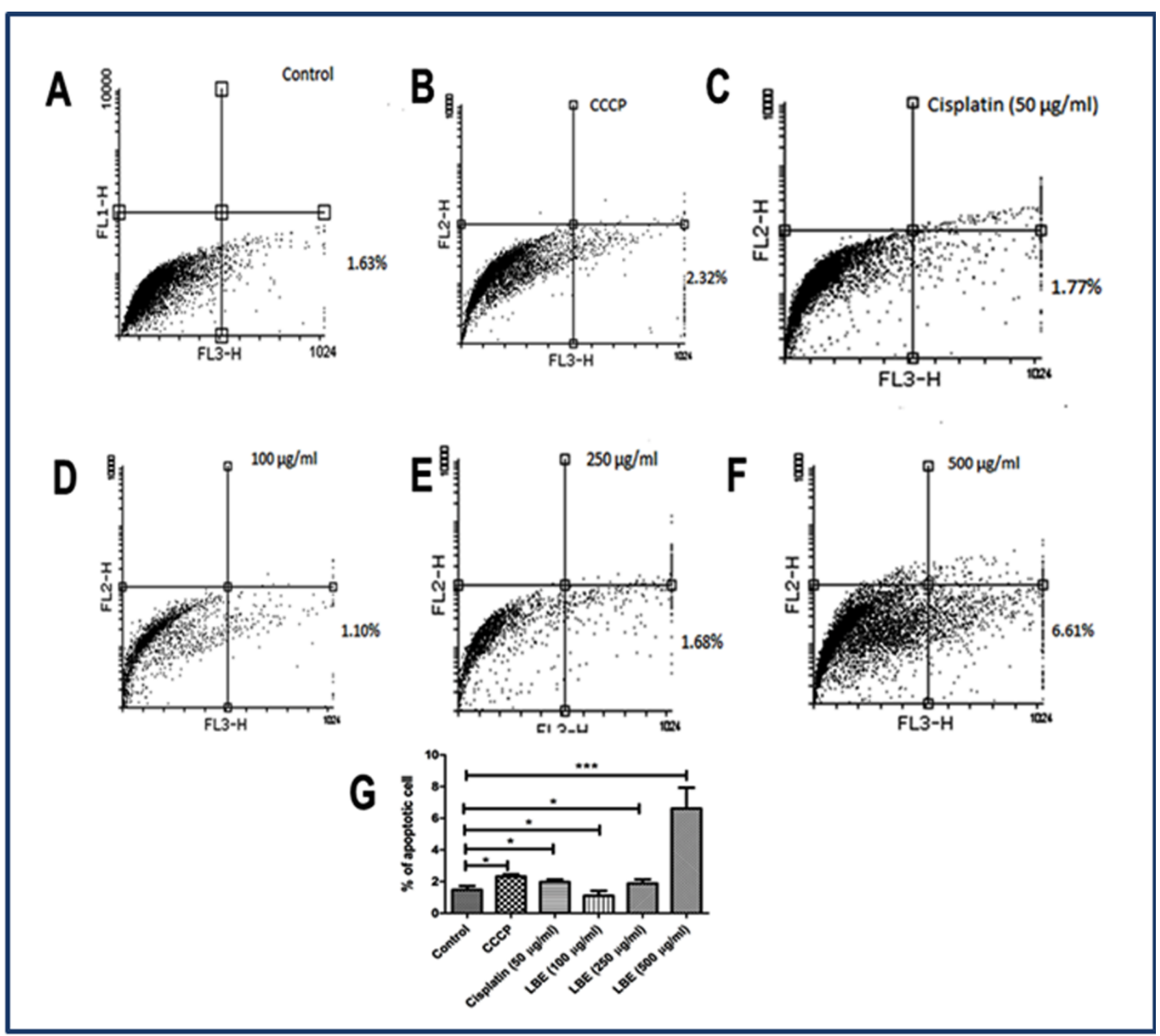

Figure 6.Flowcytometric data on mitochondrial membrane potential changes in HeLa cells. (A) Untreated (negative) cells. (B) CCP treated. (C) Cisplatin $(50 \mu \mathrm{g} / \mathrm{ml})$. Treated cells (D, E, F, G), graph (\% apoptotic cells).Data are representative as a mean \pm SEM of three independent experiments indicates $* \mathrm{p}<0.05, * * \mathrm{p}<0.01, * * * \mathrm{p}<0.001$ as compared to control

Figure 7. 


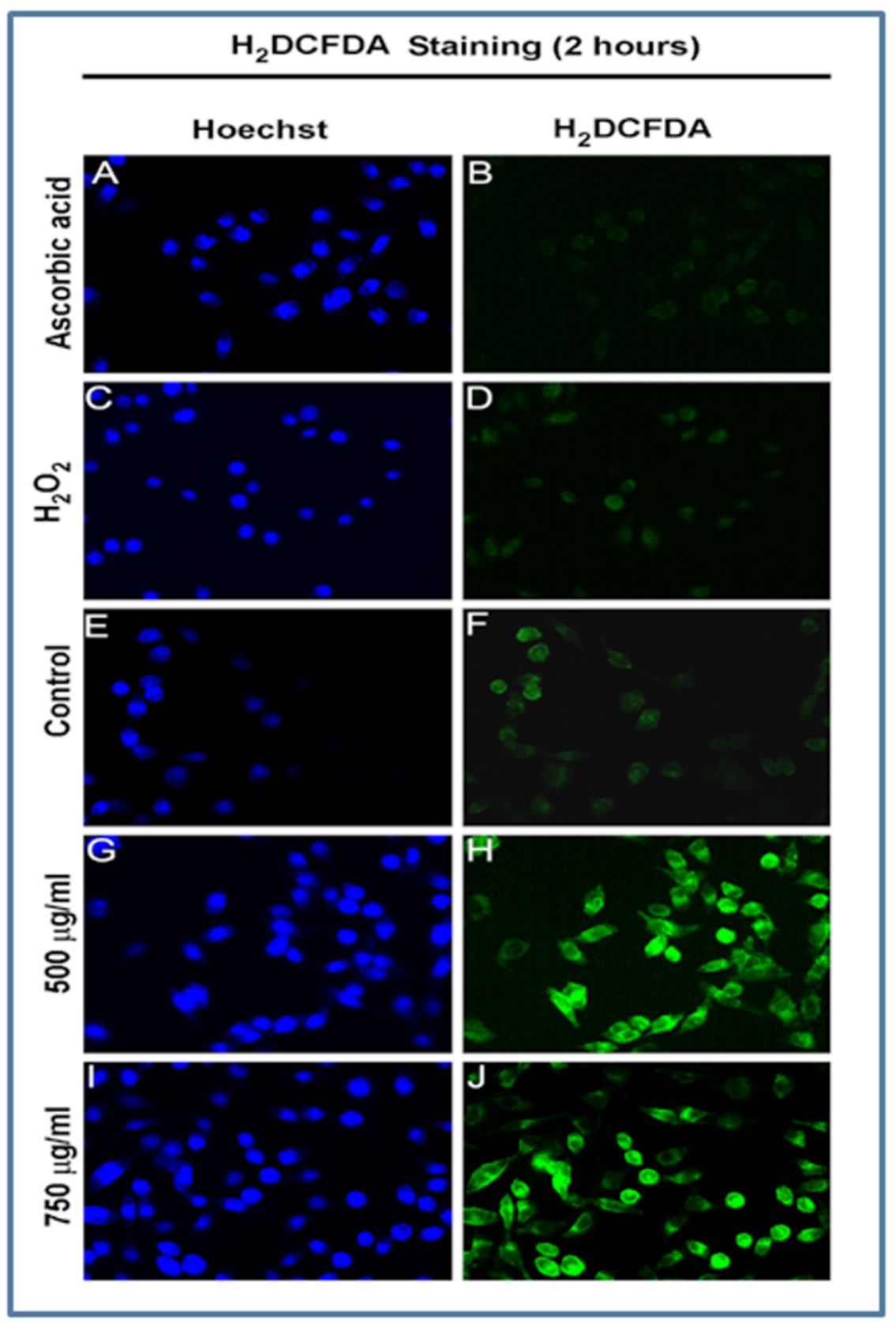

Figure 7.Detection of ROS using carboxy $-\mathrm{H}_{2}$ DCFDA dye. HeLa cells were treated with $\mathrm{H}_{2} \mathrm{O}_{2}$ were compared to non-treated cells. ROS induces the modification of carboxy- $\mathrm{H}_{2} \mathrm{DCFDA}$ that fluoresces green as detected by flow cytometry, the fluorescent peak in $\mathrm{H}_{2} \mathrm{O}_{2}$ treated cells shift compared to the peaks in controls $\left(\mathrm{H}_{2} \mathrm{O}_{2}\right.$ treated cells stained with oxidation insensitive dye and non-treated cells stained with carboxy- $\mathrm{H}_{2}$ DCFDA) . Results confirm the presence of ROS in treated cells. 
Figure 8.

A

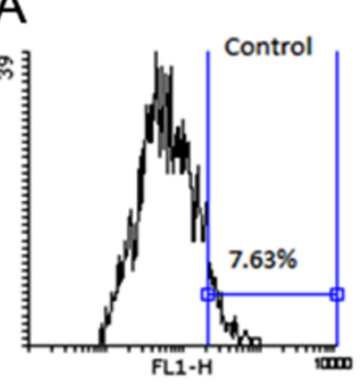

D

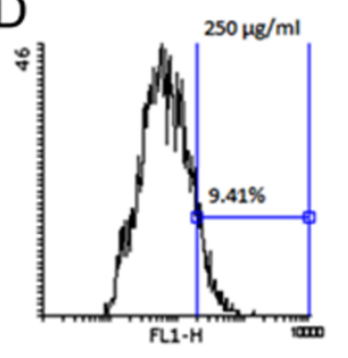

B

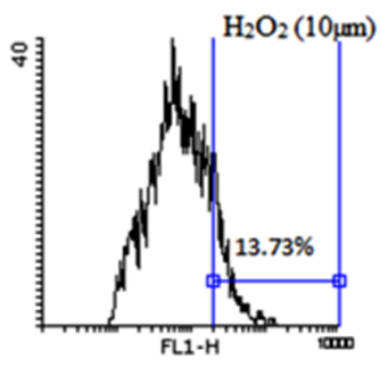

$E$

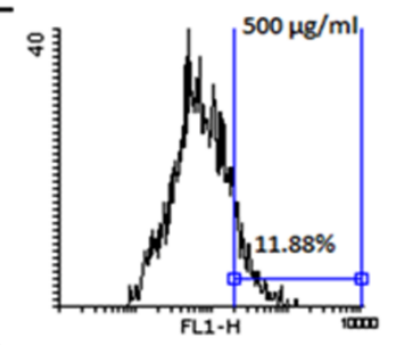

C

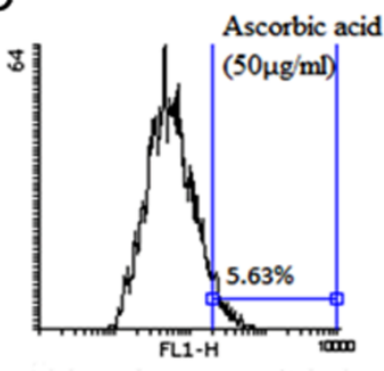

$\mathrm{F}$

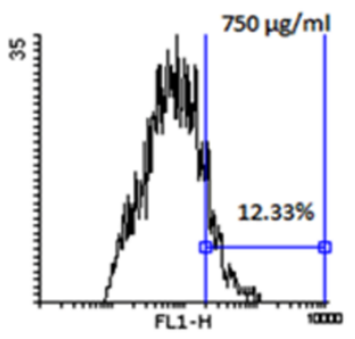

G

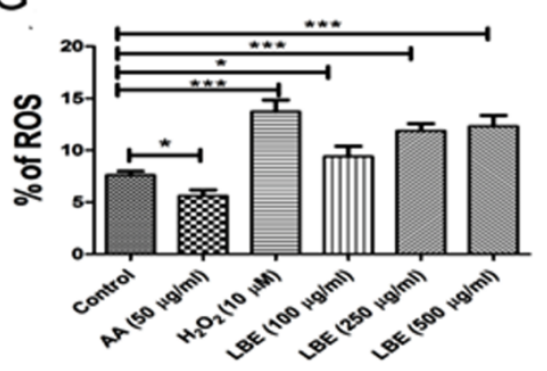

Figure 8. Flow cytometry data of intracellular ROS generation. Untreated (negative) (A), $\mathrm{H}_{2} \mathrm{O}_{2}$ (B), Ascorbic acid (C), treated (D, E, F).Percentage of ROS generation graph (G). Data are representative as a mean \pm SEM of three independent experiments indicates ${ }^{*} \mathrm{p}<0.05,{ }^{* *} \mathrm{p}<0.01,{ }^{* * *} \mathrm{p}<0.001$ as compared to control 
bioRxiv preprint doi: https://doi.org/10.1101/540567; this version posted February 5, 2019. The copyright holder for this preprint (which was not certified by peer review) is the author/funder, who has granted bioRxiv a license to display the preprint in perpetuity. It is made available under aCC-BY 4.0 International license.

Figure 9

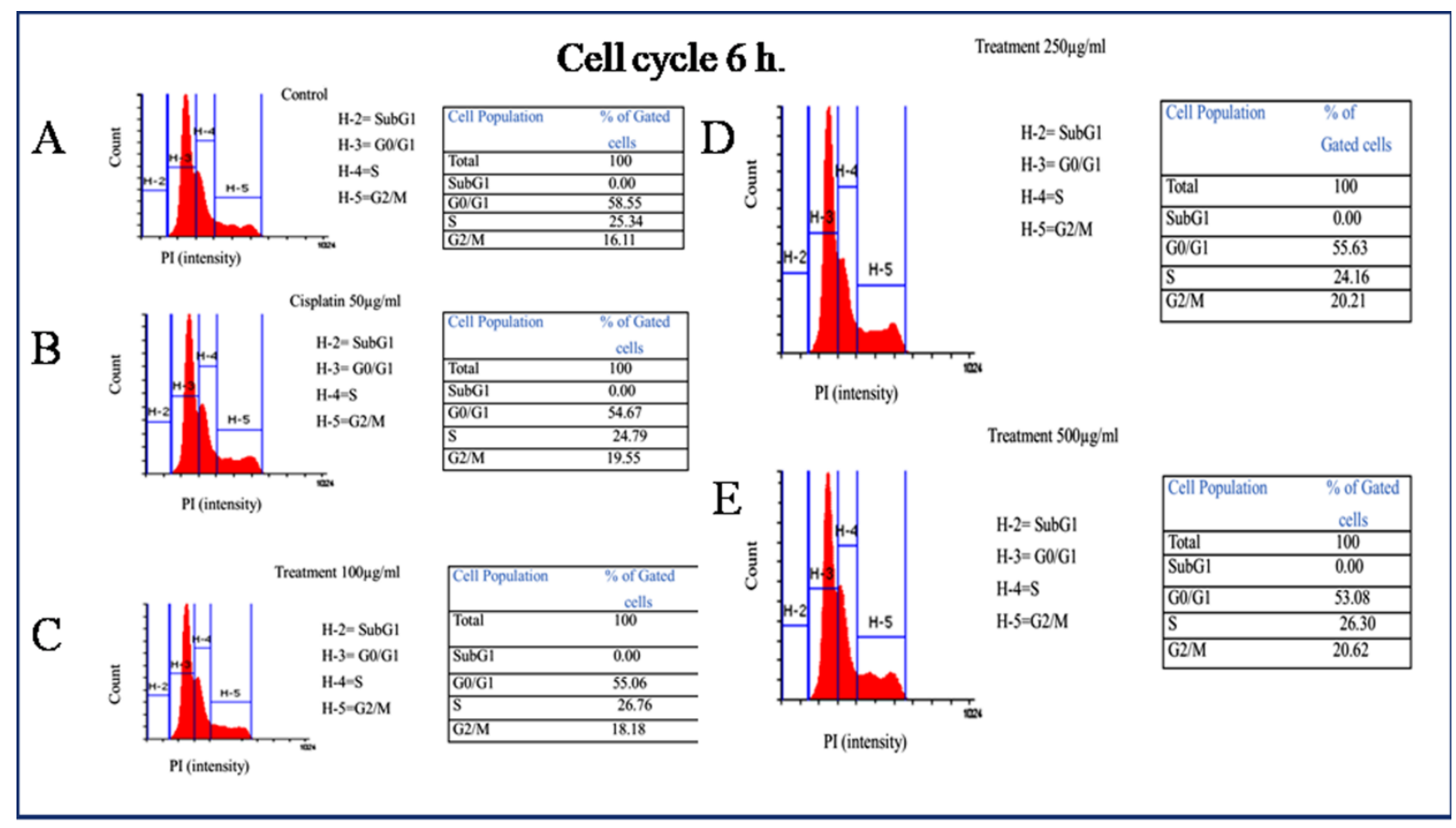

Figure 9 \&10. (A) Control (negative).(B, C, D \&E) LBE interferes with cell cycle population by inducing G2/M arrest of HeLa cell in vitro, in $6 \mathrm{~h}$ and $12 \mathrm{~h}$. 
bioRxiv preprint doi: https://doi.org/10.1101/540567; this version posted February 5, 2019. The copyright holder for this preprint (which was not certified by peer review) is the author/funder, who has granted bioRxiv a license to display the preprint in perpetuity. It is made available under aCC-BY 4.0 International license.

Figure 10.

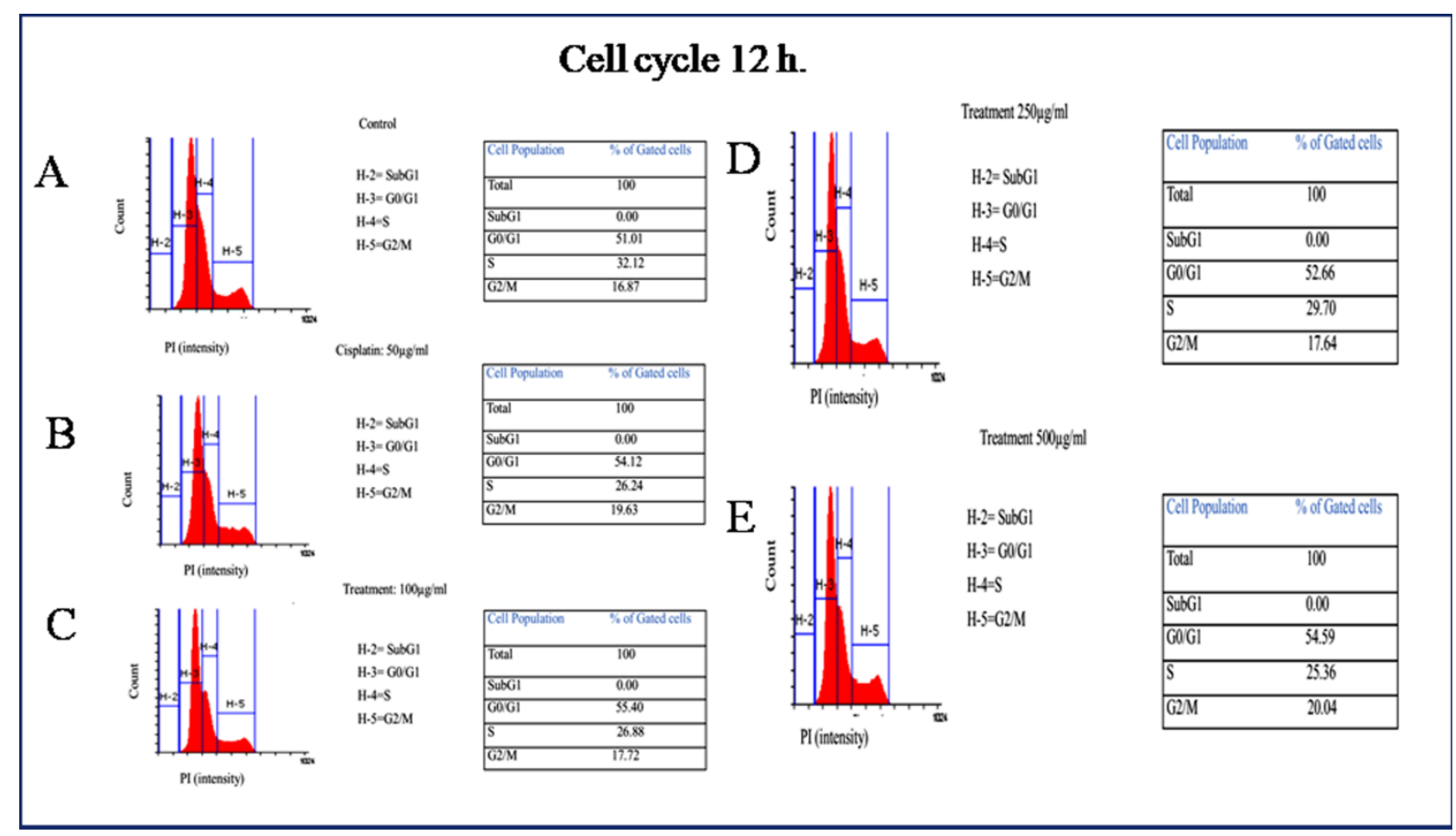

Figure $9 \& 10$. (A) Control (negative).(B, C, D \&E) LBE interferes with cell cycle population by inducing G2/M arrest of HeLa cell in vitro, in $6 \mathrm{~h}$ and $12 \mathrm{~h}$. 
Figure 11.

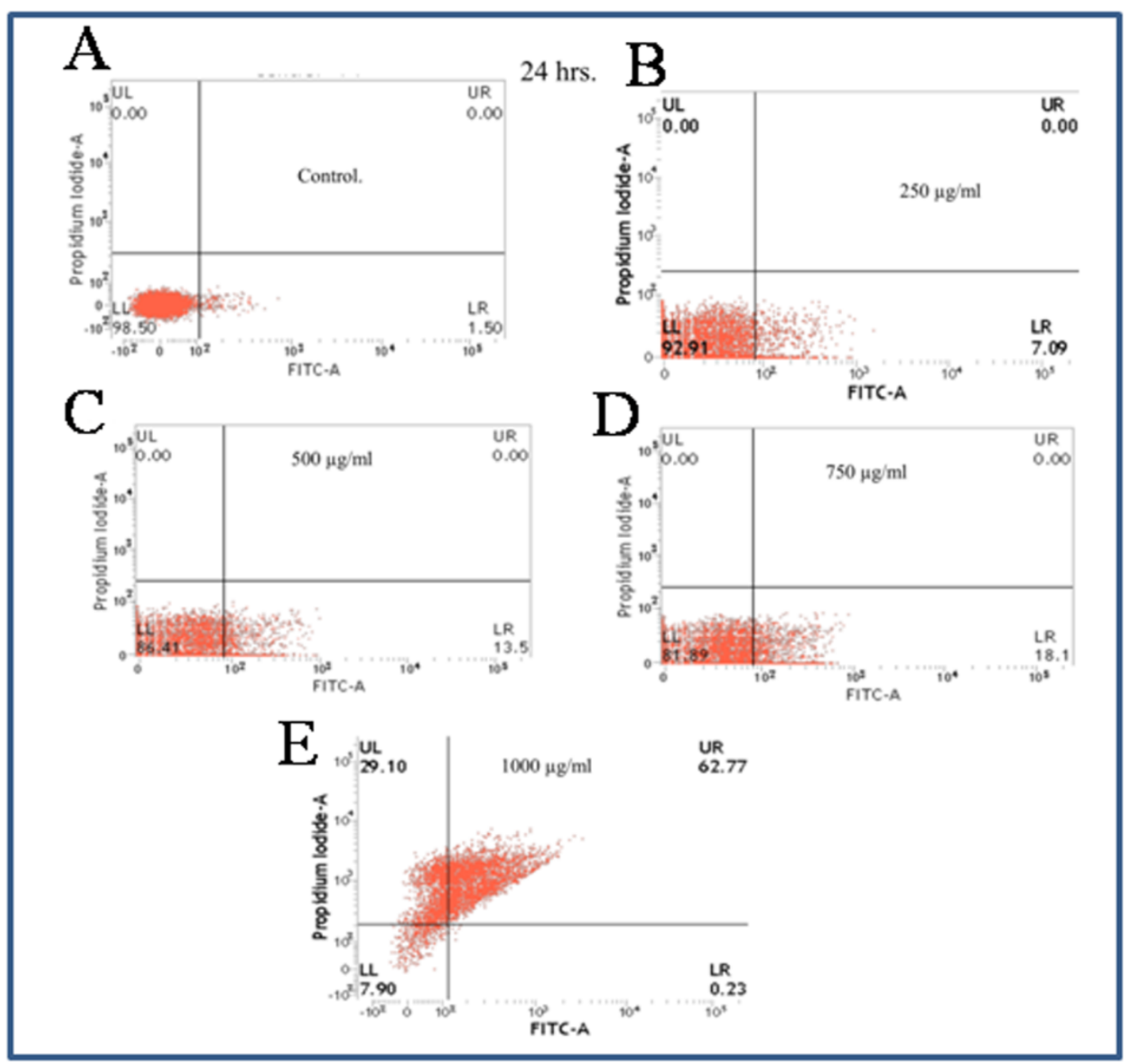

Figure 11.Annexin V Assay in HeLa cells in vitro by FACS. (A) Control (Negative) cells. (B, C, D, \& E) treated cells. Quadrants: lower left: live cells; lower right: apoptotic cells; upper right: late apoptotic cells; and upper left: necrotic cells.. Data are representative as a mean \pm SEM of three independent experiments indicates $* \mathrm{p}<0.05, * * \mathrm{p}<0.01, * * * \mathrm{p}<0.001$ as compared to control. 
Figure 12.

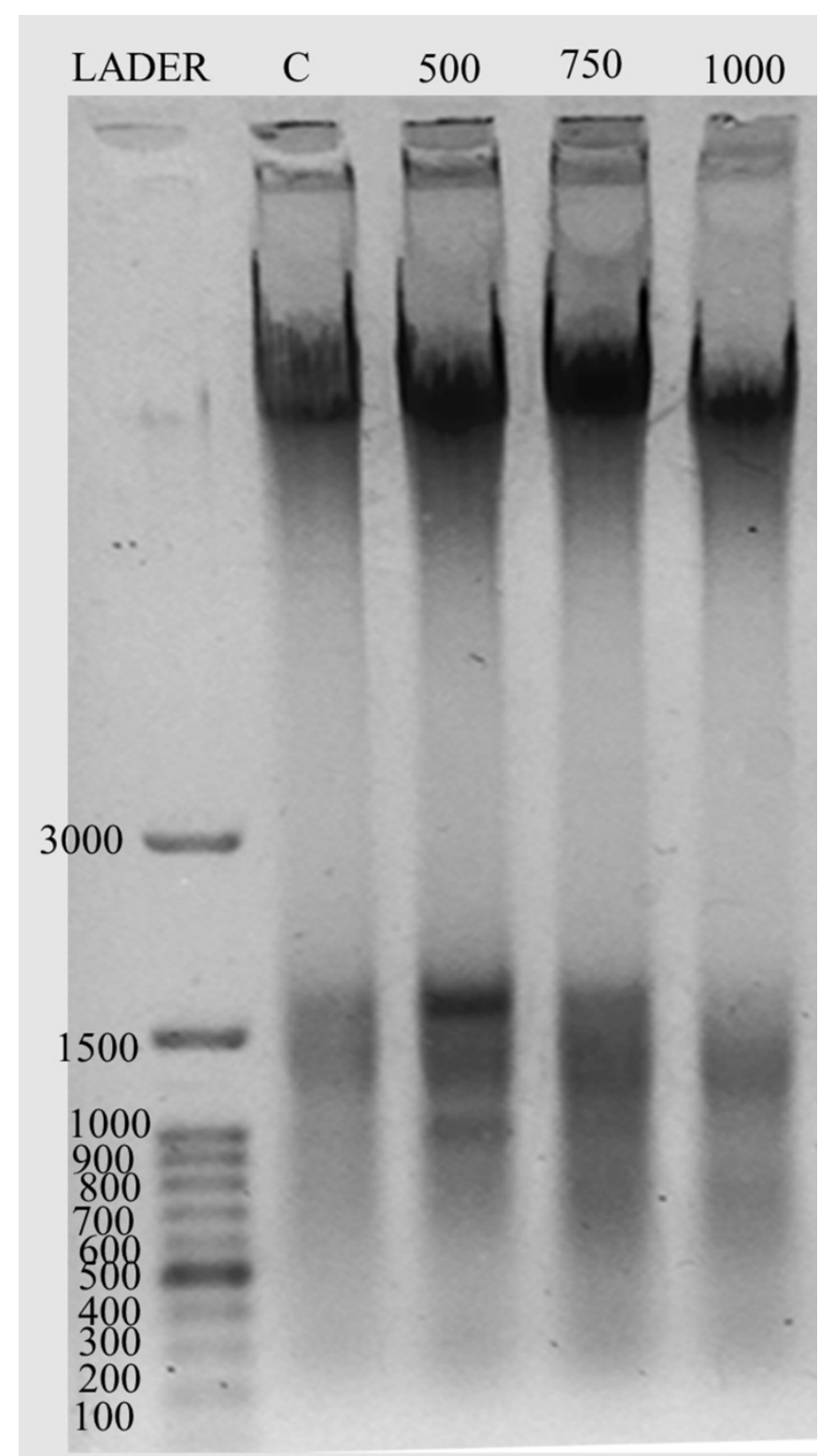

Figure12. DNA ladder assay. Genomic DNA from HeLa cells was isolated and subjected to electrophoresis in agarose gel (1.8\%) and Control (negative) (C) lane showed no fragmented DNA but $1000 \mu \mathrm{g} / \mathrm{ml}$ showed fragmented DNA in the form of ladder after $24 \mathrm{~h}$ DNA fragments were visualized under a UV trans-illuminator and compared with a standard marker. 
Figure13.

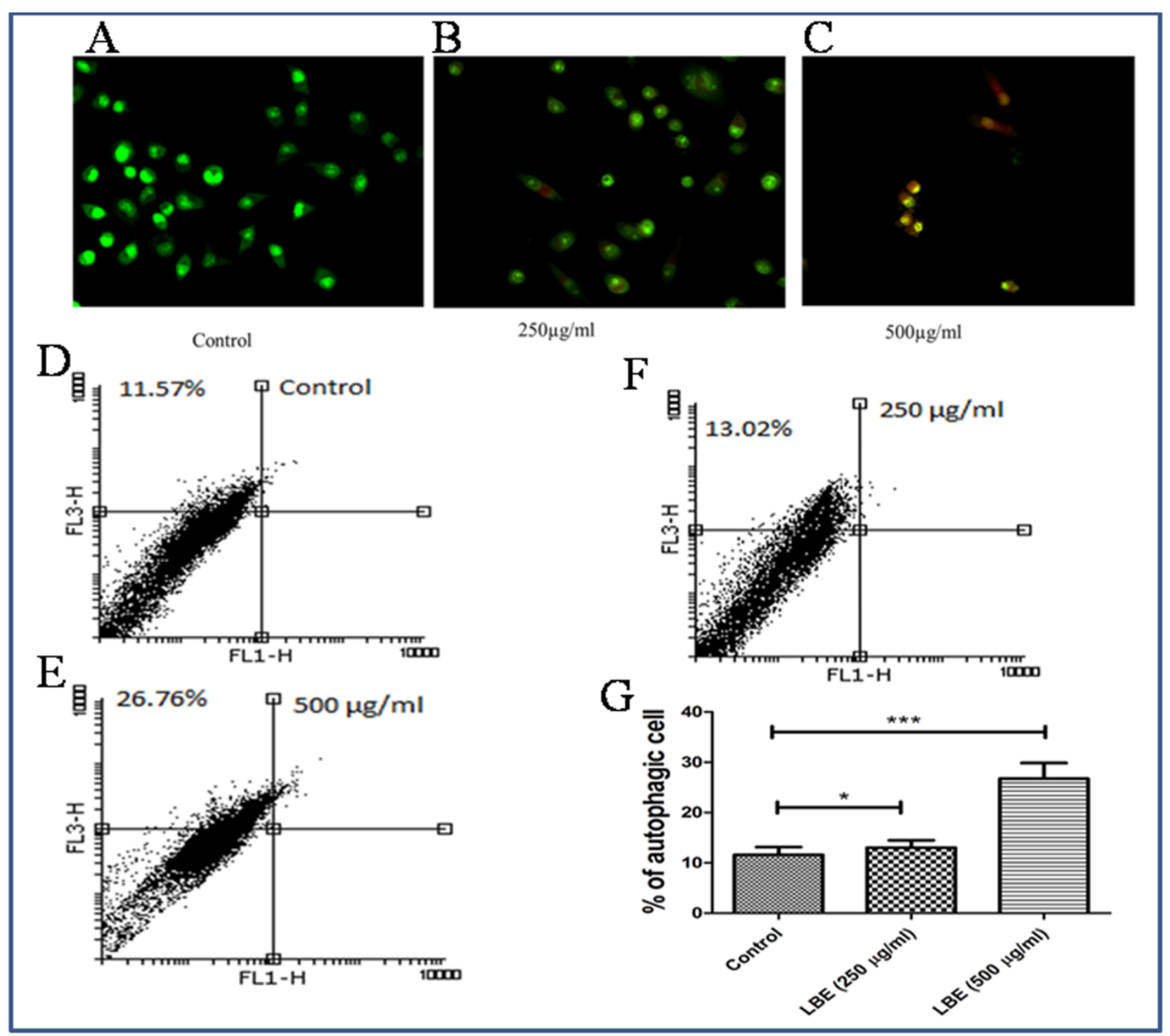

Figure 13.Autophagy of LBE treated in HeLa cell. Fluorescence microscopic image of autophagic cells (A) Negative control, (B \&C) treated. (D). Untreated (negative) cells, (E \& F).Treated cells, $(\mathrm{G})$.graph (\% autophagic cells.Data are representative as a mean $\pm \mathrm{SEM}$ of three independent experiments indicates $* \mathrm{p}<0.05, * * \mathrm{p}<0.01, * * * \mathrm{p}<0.001$ as compared to control. 
bioRxiv preprint doi: https://doi.org/10.1101/540567; this version posted February 5, 2019. The copyright holder for this preprint (which was not certified by peer review) is the author/funder, who has granted bioRxiv a license to display the preprint in perpetuity. It is made available under aCC-BY 4.0 International license.

Figure14.

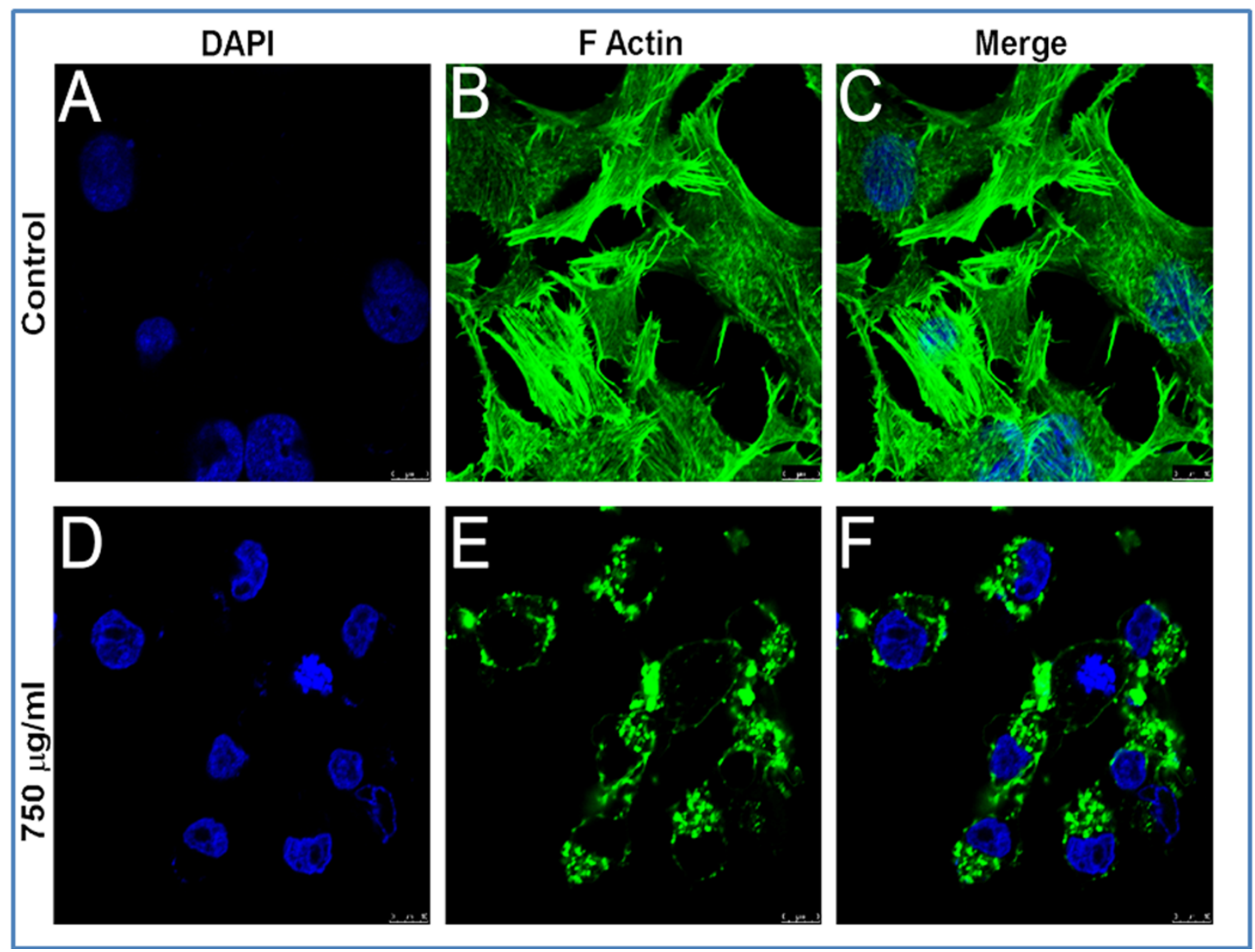

Figure 14.F-actin analysis by confocal microscopy of LBE treated HeLa cell. Control (negative): (A) (DAPI), (B). (F-actin), and (C). (Merged).Treated: (D). (DAPI), (E). (F actin), and (F) (Merged). 
Figure15.

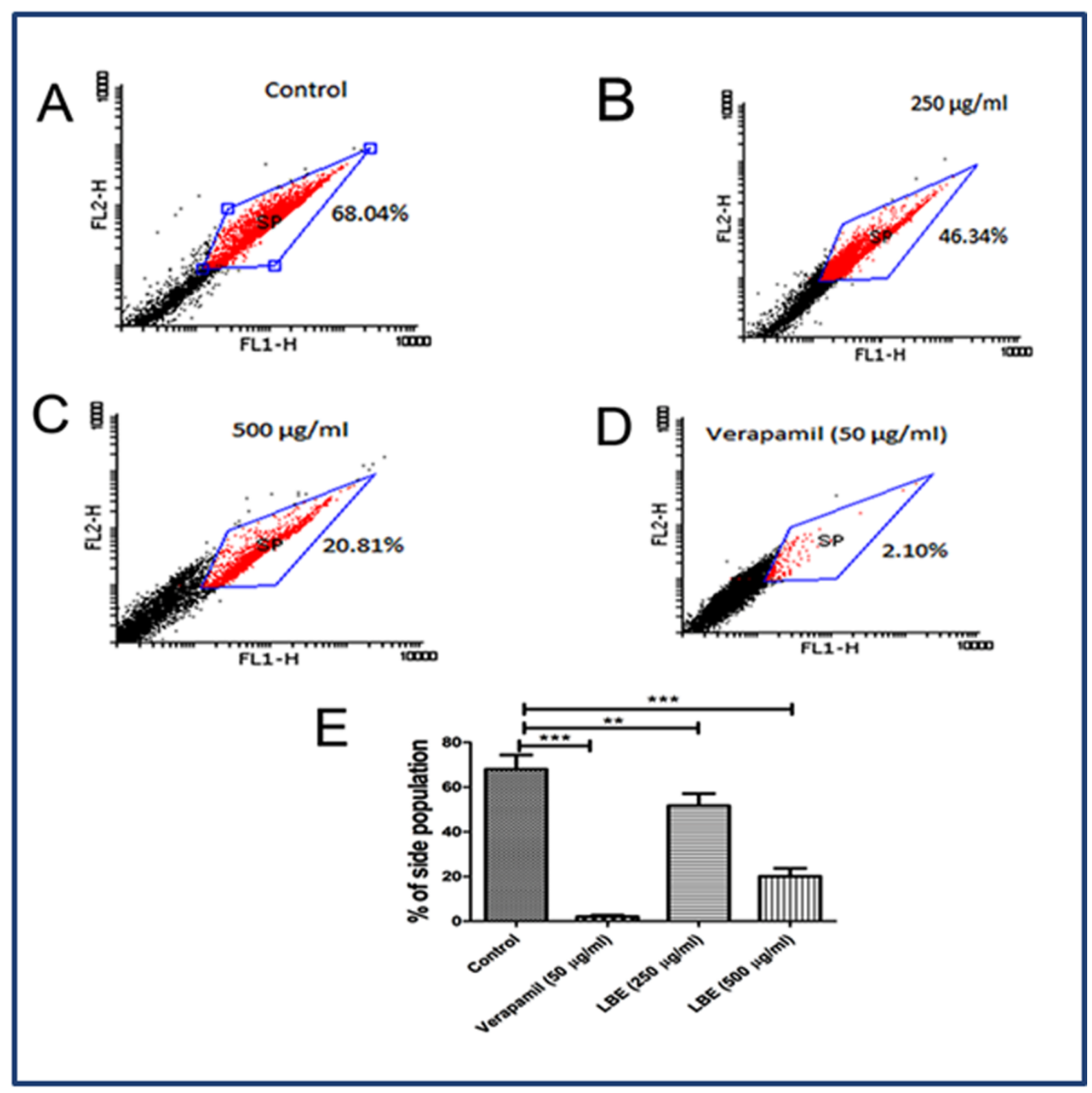

Figure 15.Flow cytometry profiling of stem cell side population. (A). Control (negative), (B\&C). Treated (D), Positive control (E). Bar diagram (\% of stem cell side population). 
Figure16

\section{Expression pattern of different apoptotic protein after treatment}
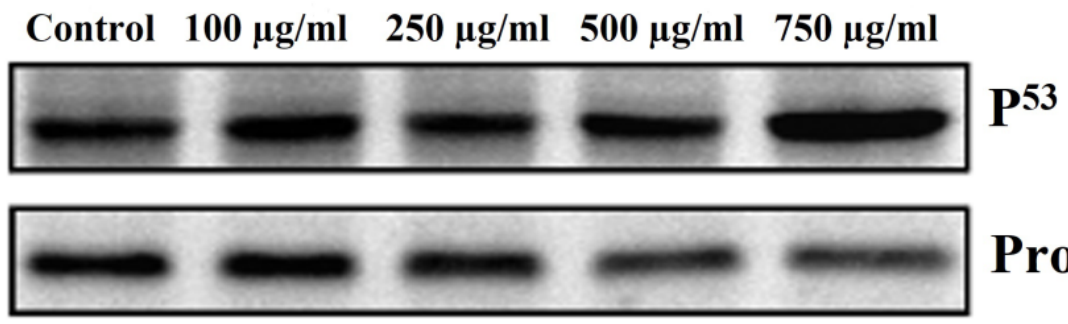

Pro Caspase 3

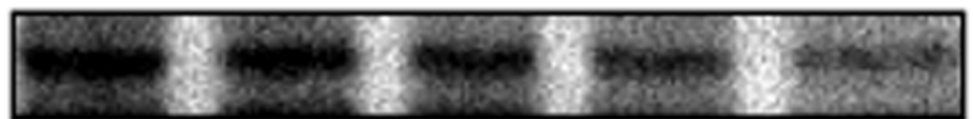

Pro Caspase 9

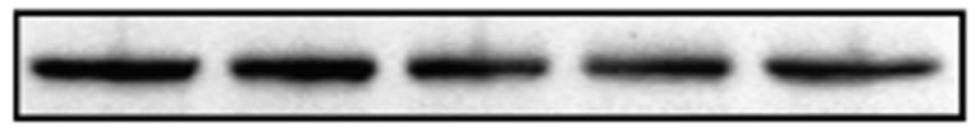

PRAP

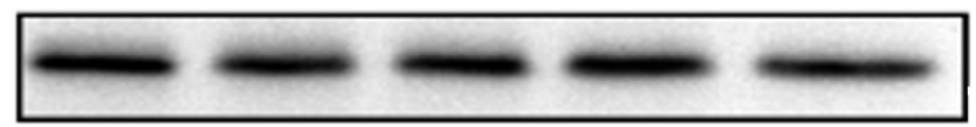

\section{Bcl2}

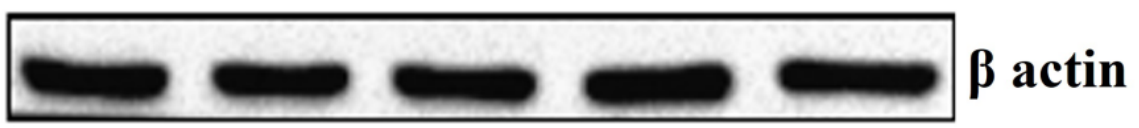

Figure 16. Western immunoblot analysis. Alteration in the expression of p53 pro- caspase 3 procaspase 9 BcL-2 and PRAP: Equal loading of protein in the lanes was confirmed by beta actin. 
bioRxiv preprint doi: https://doi.org/10.1101/540567; this version posted February 5, 2019. The copyright holder for this preprint (which was not certified by peer review) is the author/funder, who has granted bioRxiv a license to display the preprint in perpetuity. It is made available under aCC-BY 4.0 International license.

Figure17.

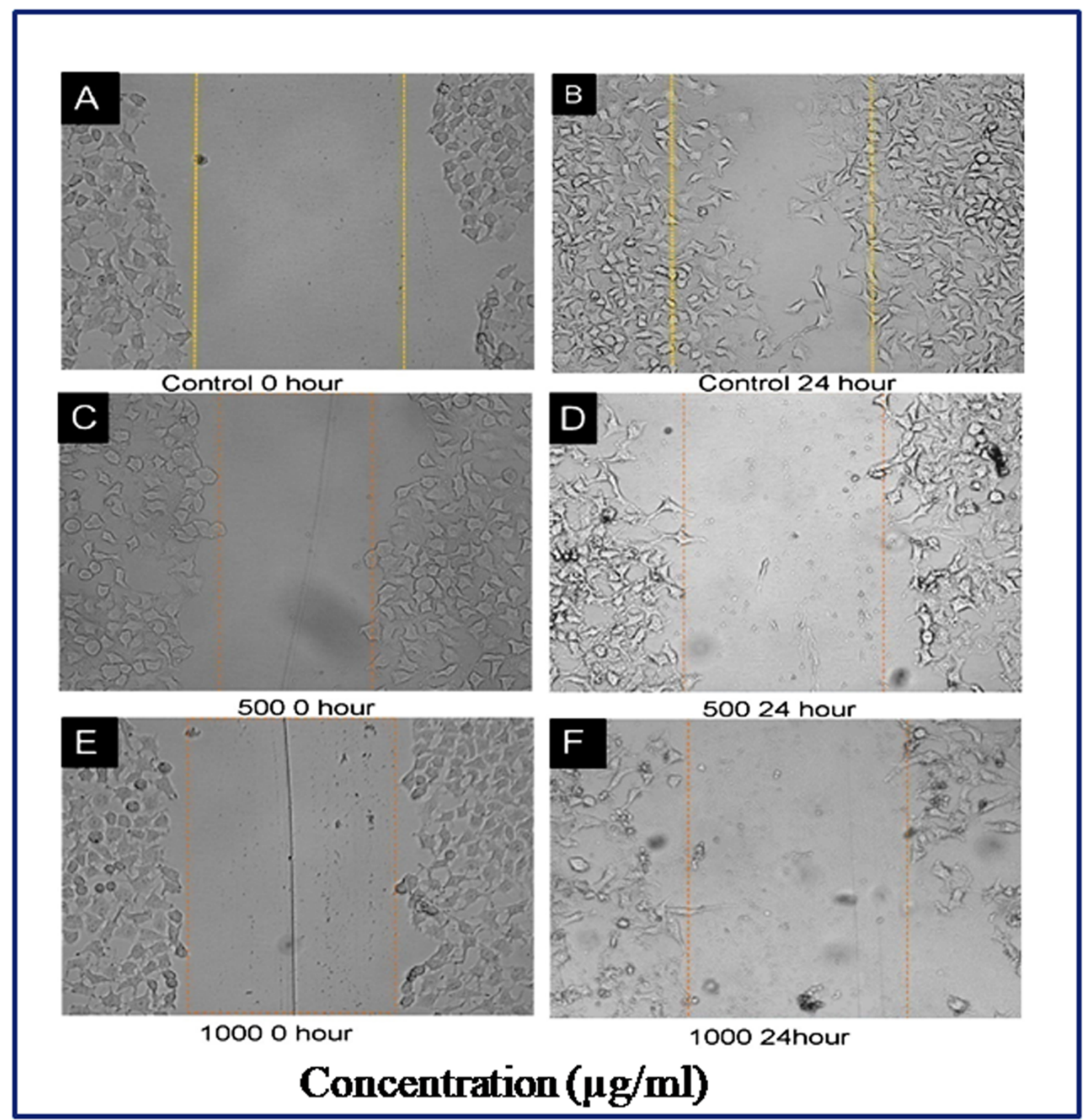

Figure 17.Effect LBE on migration of HeLa Cells in scratch method. (A) No cell migration in control (negative) at $0 \mathrm{~h}$. (B) Cell migration in control at $24 \mathrm{~h}$. Treated cell $0 \mathrm{~h}(\mathrm{C}, \mathrm{E})$ and $24 \mathrm{~h}(\mathrm{D}$, F). 
bioRxiv preprint doi: https://doi.org/10.1101/540567; this version posted February 5, 2019. The copyright holder for this preprint (which was not certified by peer review) is the author/funder, who has granted bioRxiv a license to display the preprint in perpetuity. It is made available under aCC-BY 4.0 International license.

Figure18.

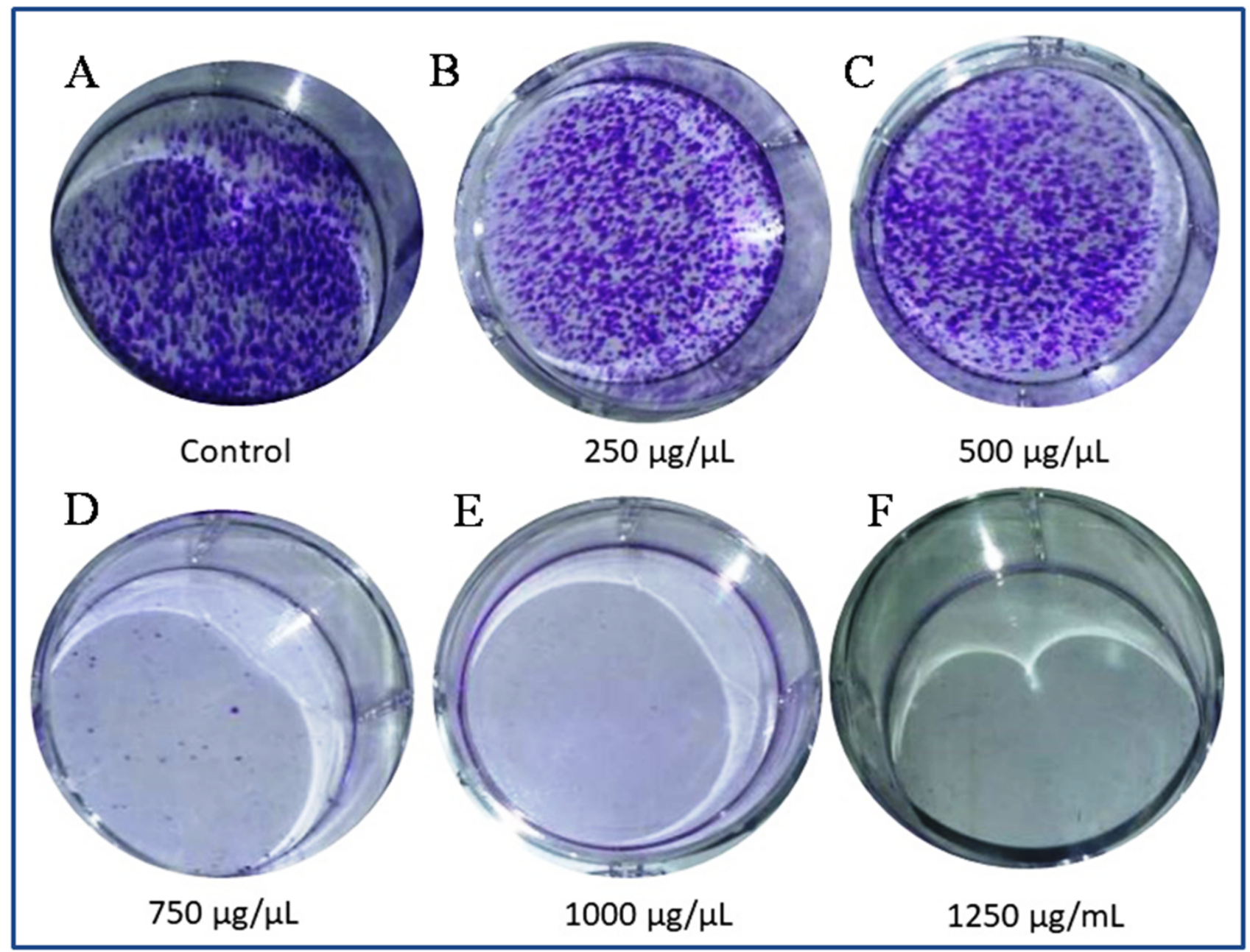

Figure 18.Effect of LBE on colony formation of HeLa cells in vitro. (A) Control (negative). Treated $(\mathrm{B}, \mathrm{C}, \mathrm{D}, \mathrm{E}$, and F): dose dependent inhibition of clonogenicity in HeLa cell

Figure19. 


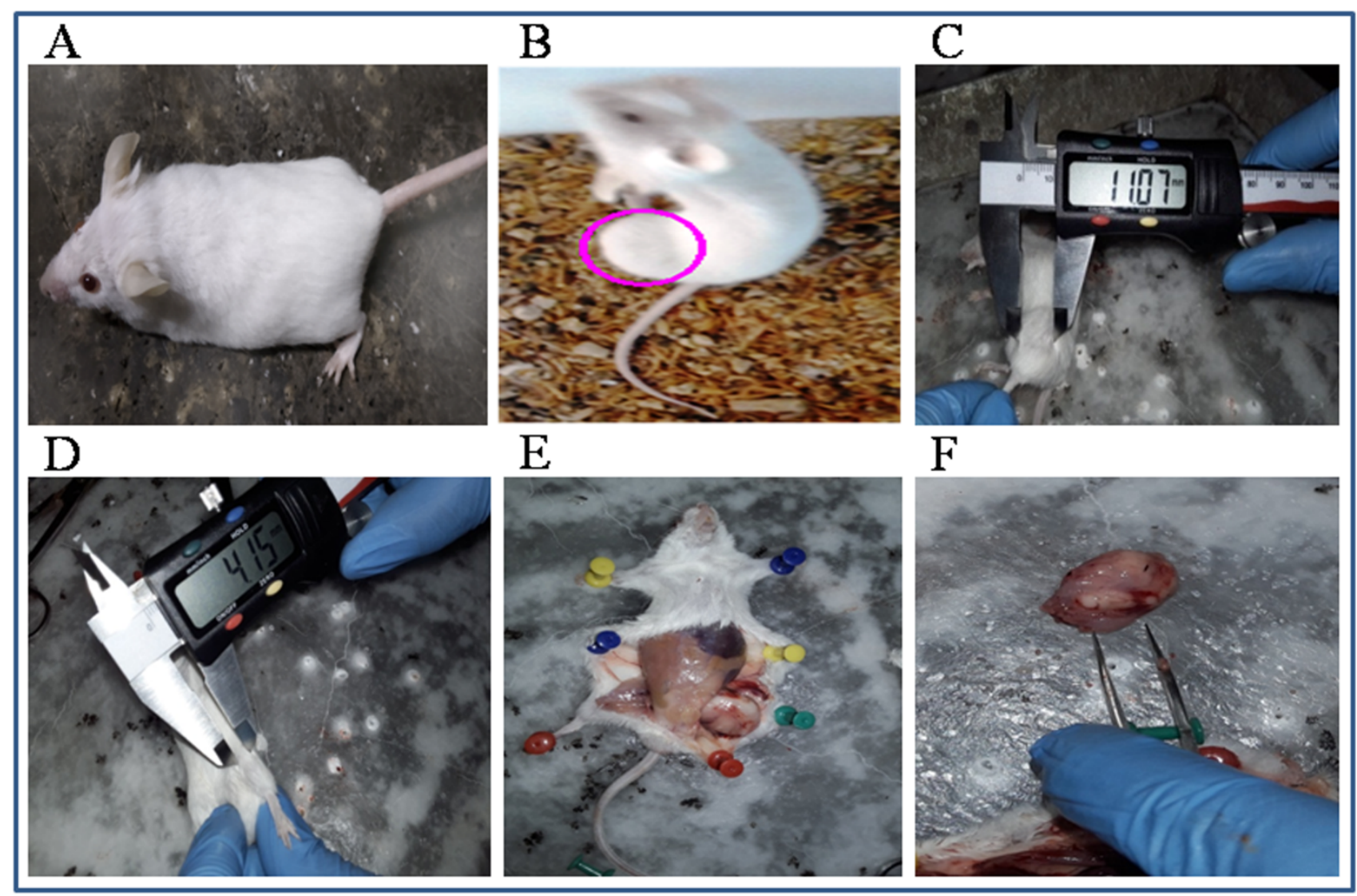

Figure 19. Effects of LBE on tumor growth on HeLa implanted mice. LBE suppresses the growth of cervical cancer tumors in swiss albino mice. Mice were inoculated subcutaneously in the right flank with $2 \times 10^{6} \mathrm{HeLa}$ cells. Tumor volume was measured twice/week using a caliper and calculated as $(\text { width })^{2} \times$ length $/ 2$. Representative images were captured at the end of therapy, (A) shows control mice (B) Tumor bearing mice, (C) measurement of tumor treated (LBE $10 \mathrm{mg} / \mathrm{kg}$ body weight), (D) measurement of tumor treated ( LBE $50 \mathrm{mg} / \mathrm{kg}$ body weight), (E) sacrificed mouse (dissected), (F) tumor dissection from sacrificed mice. 
Figure20.

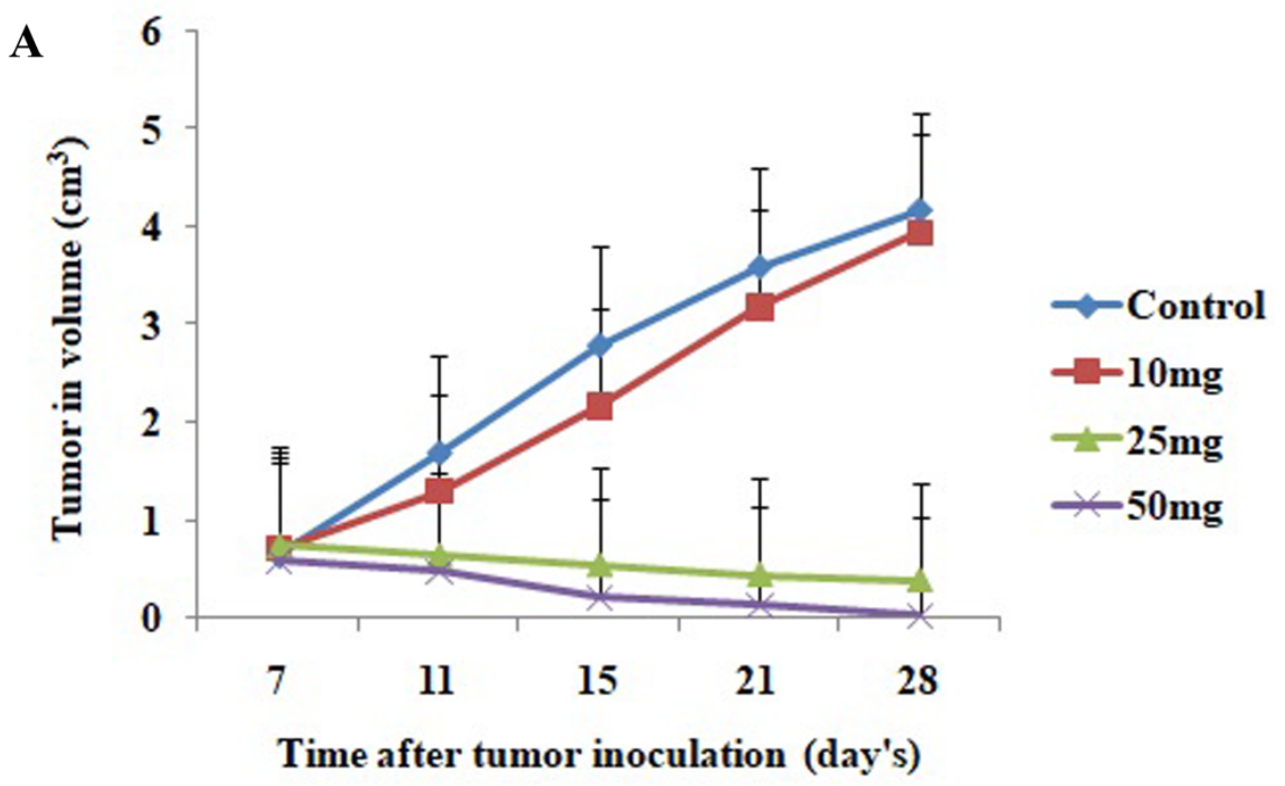

Figure 20.Graphical representation (line plot) of the effects of LBE on tumor growth (volume) in vivo. $\mathrm{mg} / \mathrm{kg}$ indicates $\mathrm{mg} \mathrm{LBE}$ per $\mathrm{kg}$ body weight of mice. The data represented as mean $\pm \mathrm{SD}$ for the three different experiments performed in triplicate. Error bars of $\pm \mathrm{SD}$ are inserted in figure

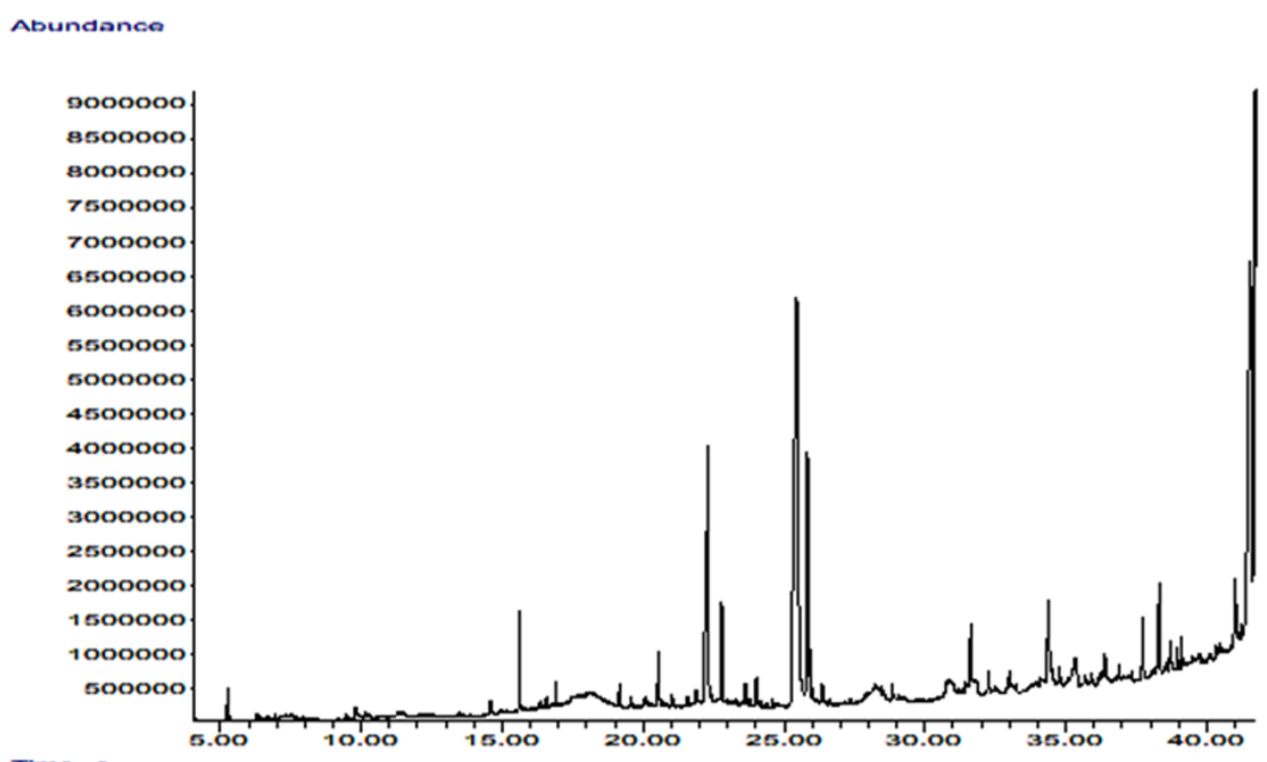

Figure21. 
bioRxiv preprint doi: httos://doi org/101101/540567: this version posted Februarv 5,2019 . The copvriaht holder for this preprint (which was not certified by peer review) is the author/funder, who has granted bioRxiv a license to display the preprint in perpetuity. It is made available under aCC-BY 4.0 International license.

Figure21. GC-MS chromatogram 
bioRxiv preprint doi: httos://doi.org/10 1101/540567: this version posted Februarv 5 2019. The copvriaht holder for this preprint (which was not certified by peer review) is the author/funder, who has granted bioRxiv a license to display the preprint in perpetuity. It is made available under aCC-BY 4.0 International license. 